\title{
THE CONSTITUTIONAL POWER OF THE PRESIDENT TÓ CONCLUDE INTERNATIONAL AGREEMENTS
}

\section{GRAIG MATHEWS广}

ONE of the most important constitutional issues of recent times is the extent to which the Constitution confers upon the President independent authority to conclude international agreements. ${ }^{1}$ As the exigencies of foreign relations impose continually increasing burdens upon those who shape our international policies, this problem assumes an ever greater significance. The recent and evidently unfinished controversy regarding the proposed Bricker Amendment indicates in dramatic terms an awareness both of the immediacy of the question and of the underlying policies which are at stake.?

The many attempts to resolve this problem have made it clear that no answer is sufficient which does not recognize the primary importance of an effective foreign policy in the contemporary world. It need not be demonstrated how little this world resembles that of the men who drafted the Constitution nearly two centuries ago. We face, as much as they, the necessity of achieving coherent national policy, representative of the national interest and responsible to other nation-states, without in the process sacrificing individual liberties and democratic methods to authoritarian expediency. Our solution, like theirs, must inevitably take the form of compromise. But the solution which will be found adequate today must be based upon the requirements of survival as a democratic body politic in the contemporary international arena, not that of 1787.3

$\dagger$ Member, Ohio Bar.

1. The ambiguity in the phrases "to conclude international agrecments" and "to make international agreements" is recognized. For greatest clarity it is often nceessary" to analyze the making of international agreements as a series of functional steps, such as: (a) formulation of policies; (b) conduct of negotiations; (c) validation of the agreement as the internal law of the land; and (d) final utterance or ratification of the agreement as an international obligation. See McDougal \& Lans, Treaties and Congression:olExecutive or Presidential Agreements: Interchangcable Instruments of Notional Policy, 54 YALE L.J. 181, 202 (1945). The context below will make clear the sense in which these phrases are used.

2. For discussion of the Bricker Amendment and collection of the literature, see Bricker \& Webb, Treaty Law vs. Domestic Constitutional Low, 29 Norre Dasse LAw. 529 (1954); MacChesney, The Fallacies in the Case for the Bricker Amendment, 29 Nonve DaMre Law. 551 (1954); Perlman, On Amending the Trealy Pourer, 52 CoL L. Rev. 825 (1952).

3. For this reason alone, quite apart from the question of the intent of the founding fathers, it is dangerous to seek to judge the scope of presidential forcign affairs power today by the practice of nations two centuries ago. For an extreme example of this approach, see Fraser, The Constitutional Scope of Treaties and Execufive Agrecments, 31 A.B.A.J. 286 (1945). The author concedes a narrow constitutional authority in the President to make agreements under his "diplomatic" and Commander in Chief powers, 
Any study of this subject must be largely a history of our practice in the making of international agreements; there is very little "case law," for the problems posed by these agreements rarely reach the courts. The relevant practice demonstrates a long-continued recognition by all branches of the government of the broad scope of the President's powers in foreign relations. It shows also that in times of crisis the scope of presidential powers must be broader than in less critical periods ; ${ }^{4}$ and that this concession of power has never been regarded as incompatible with the preservation of a democratic government. A study of prior practice will indicate what the pressures of foreign relations have demanded and what common consensus has atthorized from our agreement-making processes in the past. This data, together with a projection of probable future exigencies, is the most realistic gauge available of the desirable scope of these presidential powers.

Traditionally, the conclusion of international agreements has constituted one of the most important techniques, indispensable to the general conduct of diplomacy, by which the executive has sought to make the nation's foreign policy effective. The President's authority to make such agreements has consequently been regarded as co-extensive with his powers generally in the field of foreign affairs. It will accordingly be necessary to outline in detail these various substantive powers. It is these powers which define and limit the scope of the President's competence to make agreements.

The nature of the President's foreign affairs power is not fully indicated by a superficial reading of the Constitution. Various conflicting grants of power

and admits that it may, unhappily, be too late to curb a few other varietics of presidential agreements commonly (although, one gathers, unconstitutionally) entered into in the past. As to all other international agreements, he concludes that, "where no rational doubt exists as to the fact that their subject matter is of the general type cmbodied in treaty form in the eighteenth century," they can still be undertaken only as treaties. Id. at 288 .

4. Experience demonstrates "a recurring pattern of strong executive authority in war, followed by a strong counter-assertion of legislative authority." Cheever \& HAviland, American Foreign Policy and the Separation of Poivers 6 (1952). A dramatic illustration is found in the actions of President Lincoln during the critical days of the Civil War. His most extreme proclamation subjected civilians accused of disloyalty to trial by military commission even in areas where the regular courts were still properly functioning. The Supreme Court took refuge in technicality to avoid the neccssity of holding the President's action unconstitutional while the war was actually in progress. See Ex parte Vallandigham, 1 Wall. (68 U.S.) 243 (1864). Not until a year after the emergency was past did the Court declare, in Ex parte Milligan, 4 Wall. (71 U.S.) 2 (1866), that the President could never constitutionally have possessed the power which it in effect had permitted him to exercise during the period of crisis. See Rossiter, The Surwese Court and the Consarander in ChIEF 26-39 (1951). See also the cases arising out of the evacuation (in effect ratified by Congress) of Japanese-Americans from the West Coast during World War II, particularly Korematsu v. United States, 323 U.S. 214 (1944). Even the various opinions in Youngstown Sheet \& Tube Co. v. Sawyer, 343 U.S. 579 (1952), seem to indicate that, in the absence of explicit congressional prohibition, a majority of the Court believed that the President might validly have scized the mills in question if the emergency had been sufficiently great. See Frank, The Futurc of Presidential Seizure, Fortune, July, 1952, p. 70. 
to act in the international arena are made to the several branches of the Federal Government. Thus, Congress has the power to regulate interstate and foreign commerce; to declare war; to provide, maintain, and regulate the armed services; to exercise the taxing power in order to provide for the common defense and general welfare; and to implement, through the necessary and proper clause, all the powers possessed by the national government." Similarly, Article II of the Constitution confers upon the President several powers essential to the conduct of foreign affairs: $\mathrm{He}$ is authorized to receive representatives from foreign governments, ${ }^{6}$ to nominate representatives to foreign governments, and to make treaties in conjunction with two-thirds of the Senate. ${ }^{7}$ And far broader powers accrue to him as Commander in Chief, ${ }^{8}$ as Chief Executive ${ }^{8}$ and under his obligation to see that the laws are faithfully executed. ${ }^{10}$ Finally, Article II, section 2 grants to the Senate the power to approve or disapprove all treaties submitted to it by the President. Even a casual reading of these provisions indicates the extent to which, in any particular set of circumstances, they are likely to come in conflict. History bears out this impression. One of the best-known commentators has said:

"What the Constitution does, and all that it docs, is to confer upon the President certain powers capable of affecting our foreign relations, and certain other powers of the same general nature upon the Senate, and still other such powers upon Congress; but which of these organs shall have the decisive and final voice in determining the course of the American nation is left for events to resolve. ... [T] he Constitution, considered only for its affirmative grants of power which are capable of affecting the issue, is an invitation to struggle for the privilege of directing American foreign policy."11

Imperative national policy, and not logical derivations from incompatible grants of authority, has allocated and must continue to allocate the foreign affairs power among the branches of government. Constitutional language has been and must be construed in a manner which will promote the major purposes of the Constitution in particular contexts of crisis. It is as futile to attempt to extract logical consistency from the literal provisions of the Consti-

5. U.S. Const. art. I, § \&. Other powers of less obvious utility have frequently been employed in foreign affairs: for example, Congressiunal power to establish post offices, $i d$. art. I, $\S 8$, has been used to conclude agreements regarding international regulation of the mails.

6. U.S. CoNST. art. II, § 3.

7. U.S. Const. art. II, § 2, cl. 2.

8. U.S. Const. art. II, § 2, cl. 1.

9. U.S. CoNst. art. II, $\S 1$.

10. U.S. Const. art. II, § 3.

11. Corwin, The President: Office and Powers 200 (2d ed. 1941). Sce also Rerois

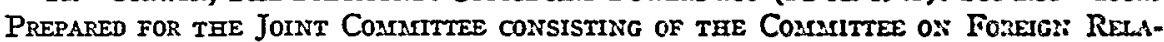
tions and the Consmittee on Arared Services of the Senate, Powers of the President to Send the Armed Forces Outsine the United States, 82d Cong., 1st Sess. 3-4 (committee print, Feb. 28, 1951) (hereafter cited as Report on Powers of tme PrestDENT). 
tution as it is dangerous to over-emphasize the powers of one branch of the government at the expense of another.

The obvious necessity that the national government possess powers adequate to meet the demands of international relations has resulted in the developmentperhaps by those who have feared without sufficient reason that the express and implied constitutional grants of power are inadequate-of the doctrine of "inherent powers" of the national Government to act in foreign affairs. These powers are said to be the automatic and necessary consequence of sovereign status in the community of nations; they are "inherently inseparable from the conception of nationality,"12 "an attribute of sovereignty."13 The historical derivation of this comprehensive national power has been disputed. This debate had its origin in the ancient case of Penhallow $v$. Doane, ${ }^{14}$ in which Justices Iredell and Patterson found themselves in disagreement whether this power originated in the several states, and passed to the national government upon ratification of the Constitution, or whether it was received by the national Government directly from the Continental Congress without ever having been possessed by the states. In 1936 the Supreme Court gave approval to the latter position in a dictum which has been the subject of considerable controversy. ${ }^{15}$ Whatever the merits of this controversy, the same exigencies of national policy which have occasioned the growth of this doctrine also require recognition of the need for adequate presidential powers in those arens of foreign affairs in which only the executive is capable of acting with the promptness and singleness of purpose essential in times of crisis.

It is apparent that consiclerations of policy underlie these abstract arguments. Theories of "inherent powers" and of a mystic transmigration of the national foreign affairs power from Crown to Federal Government, supported by the rationalization that "sovereignty is never held in suspense,"10 appear tunduly metaphysical today. But they reflect an awareness, even of the metaphysicians, that one of the major purposes of our Constitution is national survival in the world arena.

"Whatever the rationale used, it is perfectly clear that in the conduct of our international relations, the powers of the Federal Government are ample to deal with any problem, because they derive not only from the Constitution, but 'from the necessities of the case.' "17

12. United States v. Curtiss-Wright Export Corp., 299 U.S. 304, 318 (1936). Also see Corwin, The President: Office and Powers 202 (2d ed. 1941).

13. 1 Buther, The Treaty-Making Power of the United States 5 (1902). See also Cormin, The President: Office and Powers 202 (2d ed. 1941). Contra, Tuckek, Limitations on the Treaty-Making Power 98-105 (1915).

14. 3 Dall. (3 U.S.) 54 (1795).

15. United States v. Curtiss-Wright Export Corp., 299 U.S. 304, 316-17 (1936) (dictum).

16. Id. at 317.

17. McDougal \& Lans, Treaties and Congressional-Executive or Presidential Agrecments: Interchangeable Instruments of National Policy, 54 YALE L.J. 181, 260 (1945). Sce also Corwin, The President: Office and Powers 201. (2d ed. 1941). 
A brief glance at the relevant history indicates the dominant role that necessity has played in distributing the foreign affairs power among the branches of the national Government. The Presidency has possessed from the beginning inherent practical advantages which have enabled it to assume a large share of control over the foreign policy of the United States. Because the executive is relatively unified it is able to act more swiftly than a legislature divided in opinion. The President is in a position, as Congress is not, to keep negotiations and decisions secret at need. He possesses generally more adequate sources of information than does Congress in foreign matters. And he is always ready to act, unlike the legislature, which may be in recess or incapacitated by the parliamentary complications of other business. ${ }^{18}$ It is not surprising, therefore, that the President has become recognized as the leader of the nation in the conduct of its foreign affairs. The constitutional clause providing for the "Advice and Consent" of the Senate in making treaties ${ }^{10}$ has gradually come to mean no more than that the Senate retains a power of veto or amendment of the treaties negotiated by the President. As a matter of politics the President may still consult influential Senators or special committees, but the Senate as a body no longer fills the role of advisor, if indeed it ever did. ${ }^{20}$ The President has further developed the possibilities of aroiding a veto by a minority third of the Senate through increased use of his power to make international agreements independently and by combining his powers with those of the whole Congress. ${ }^{21}$ As a result, in recent years there has been a great decline in the number of treaties relative to the number of presidential and congressional-executive agreements. ${ }^{22}$ There has been no dispute that the President has certain constitutional powers not subject to the will of Congress or the Senate. And ever since the famous debate between Pacificus and Helvidius it has been

For a recent discussion of the practical considerations which have required that the President take the lead in initiating foreign policy, see Acheson, Responsibility for Dccision in Foreign Policy, 4 Yale Rev. 1 (1954).

18. Corwin, The Presment: Office ann Powers 200 (2d ed. 1941), citing TuF. Feneralist, No. 64 (Jay).

19. U.S. Const. art. II, \$2.

20. See Corwin, The President: Office and Powers 232-34 (2d ed. 1941 ).

21. For a general discussion of congressional-executive agreements, see MreDougal \& Lans, supra note 17. Employment of this technique has been frequent. Teras vas annexed in 1845 by joint resolution of Congress assented to by the President, after the Senate had defeated a treaty for this purpose. The same method was used to by-pass the treaty power in the annexation of Hawaii in 1898, and arguably would have been used also in the case of the Philippines if the Senate had, as it thrcatened, eliminated the annexation provision in the Treaty of Paris. Thus also the first World War was terminated in 1921 by joint resolution after the Senate had defented the Treaty of Versailles. And in 1934 the United States by joint resolution was enabled to join the International Labor Organization, although the defeat of the Treaty of Versailles had prevented membership previously.

22. See e.g., Wright, The United States and International Agrcemenis, 38 Ass. J. Ixr's L. 341, 345 (1944) ; Borchard, Editorial Comment, 39 Ax. J. INT'L L. 537, 539 (1945). 
generally accepted that the opening sentence of Article II, conferring upon the President the "executive power," is not declaratory merely, but makes an affirmative grant of power. ${ }^{23}$ Similarly, no one has questioned that Congress may authorize the President, as its agent, to take action in foreign affairs which would be beyond the reach of his own unaided powers. Although the outer limits of this power have never been drawn, it has been argued with reason that the combined powers of Congress and the President are plenary. ${ }^{24}$ In the field of foreign, as contrasted with domestic, affairs it is accepted that the scope of permissible delegation of congressional authority is very broad:

"Practically every volume of United States statutes contains one or more acts or joint resolutions of Congress authorizing action by the President in respect of subjects affecting foreign relations, which either leave the exercise of the power to his unrestricted judgment, or provide a standard far more general than that which has always been considered requisite with regard to domestic affairs."25

The justification for a broad delegation is generally found in the concept of "cognate powers," which was created by the Supreme Court to distinguish a delegation of domestic power from one of foreign power: the latter "confided to the President ... an authority which was cognate to the conduct by him of the foreign relations of the Government."26 The premise upon which this doctrine is founded is that the President himself has broad independent powers.

Thus, as an inevitable consequence of participation and survival in the world arena, broad executive authority to undertake international agreements has consistently been recognized..$^{27}$ And, in the agreement making process the amount of participation by the President and Congress has increased relative to that of the Senate. Recent debate has focused upon whether the treatymaking procedure can be totally by-passed through the combined powers of Congress and the President. But more fundamental and more difficult questions are raised by the relationship between the President and Congress : first, what is the scope of the President's agreement power when he acts without the authorization of Congress or the Senate; and second, to what extent can Congress constitutionally limit the President in the exercise of this power?

23. Corwin, The Constitution and World Organization $22-23$ (1944). The dispute was between Hamilton and Madison.

24. McDougal \& Lans, sipra note 17 , passim.

25. United States v. Curtiss-Wright Export Corp., 299 U.S. 304, 324 (1936).

26. Panama Refining Co. v. Ryan, 293 U.S. 388, 422 (1935). Accord, United States v. Curtiss-Wright Export Corp., 299 U.S. 304, 327 (1936); Field v. Clark, 143 U.S. 649 (1892) ; United States v. Boreno, 50 F. Supp. 520, 523-24 (D. Md. 1943); Conwin, TuE Constitution and Wordd Organization 23-24 (1944).

27. "On the whole, therefore, the net result of a century and a quarter of contest for power and influence in determining the international destinies of the country remains decisively and conspicuously in favor of the President." CoRwin, THE President's ConTROL OF FOREIGN RELATIONS 207 (1917). This proposition seems more clearly true today than when written. 
Scope of President's Independent Power to Make Agreements

Nowhere in the Constitution can there be found an explicit provision granting to the President the power to conclude international agreements without the sanction of Congress or the Senate. Yet this power has been exercised consistently since the beginning of our history. And in the process, the President has acquired the exclusive right to negotiate all agreements with foreign nations, including those concluded as treaties. ${ }^{28}$ The President's authority to enter an agreement which becomes an international obligation of the United States is so indispensable to his power to initiate foreign policy that it may reasonably be derived by implication from the language of the Constitution. Article I, section 10, which states that "No State shall enter into any Treaty, Alliance, or Confederation" and that "No State shall, without the Consent of Congress . . . enter into any Agreement or Compact with another State, or with a foreign Power," indicates that the Constitution itself recognizes the existence of international agreements other than treaties. ${ }^{20}$ Since power to make these agreements was accorded to the states with congressional consent, it would be difficult to conclude, and has never been concluded, that this power was denied to the Federal Government. ${ }^{30}$ And, in order to prevent his substantive powers under Article II from being in large measure ineffectual, the President must share in this federal power. Moved by practical considerations, and fortified by inferences from constitutional language, the courts have recognized that the President does possess this power in the few cases where the question has arisen. ${ }^{31}$ And the Congress has similarly, since the beginning of our history, accepted his exercise of such power.

The question which remains unanswered today concerns not the existence but the scope of the President's independent power to conclude international agreements. In the absence of a clause in the Constitution explicitly granting and limiting the power, its boundaries must be discovered by determining the scope of the substantive foreign affairs powers of the President; for his authority to make international agreements must be coextensive with these substantive powers if he is not to be deprived of a frequently indispensable instrument for exercising them.

Plainly, the specific grants of power to the President in Article II, together

28. "In this vast external realm, with its important, complicated, delicate, and manifold problems, the President alone has the power to speak or listen as a representative of the Nation. He makes treaties with the advice and consent of the Senate; but he alone negotiates. Into the field of negotiation the Senate cannot intrude; and Congress itself is powerless to invade it." United States v. Curtiss-Wright Export Corp., 299 U.S. 304, 319 (1936).

29. See Sutherland, The Bricker Amendment, Executize Agrcements, and Imporicd Potatoes, 67 Harv. L. Rev. 281, 287 (1953).

30. See MicDougal \& Lans, Treaties and Congressional-Executive or Presidential

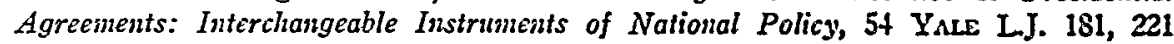
(1945).

31. See, e.g., United States v. Pink, 315 U.S. 203 (1942); United States v. Belmont, 301 U.S. 324 (1937). 
with powers which arise by implication from them, afford one source of substantive authority. There may also be said to reside in the President an "inherent" power to make decisions in foreign affairs comparable to that possessed by the national Government as a whole. ${ }^{32}$ To a degree, the structure of the Constitution supports the existence of inherent presidential powers : while the constitutional provisions conferring power on Congress in the field of foreign affair's are explicitly stated and limited, those defining the powers of the Presiclent are much more broadly drawn. ${ }^{33}$ The so-called "stewardship theory" of Theodore Roosevelt is close to this concept in supposing that the executive power of the President is limited only by specific restrictions contained in the Constitution or capable of being imposed by Congress under its own constitutional powers. ${ }^{34}$

Abstract theorizing about "inherent" or "implied" powers will not, however, aid in resolving the conflict between a literal interpretation of the Constitution and the exigencies of our foreign relations. The best indication of where the line of compromise must be drawn in an increasingly difficult future can be found by charting the areas to which the power of the President has consistently been recognized to extend in the past.

\section{Power of the President as Commander in Chief}

Probably the most important, and certainly the most dramatic, of all presidential powers is that which derives from his authority as Commander in Chief of the armed forces. Here "the Constitution confers upon the Executive his most formidable power with respect to the external relations of the country." an This power has been manifested in many ways, through different techniques, prominent among which is the independent conclusion of international agreements.

The power to make peace, although often regarded as an exclusive prerogative of the treaty-making procedure, was in fact exercised by the President alone to terminate the Civil War. ${ }^{36}$ No President has attempted to conclude a foreign war by proclamation, and the opinion was expressed by one President that this

32. "[T]he courts have recognized that the President ... has certain powers in the field of foreign affairs which are not conferred expressly by the Constitution but are derived from the fact that the United States is a sovereign nation, with rights and abligattions under the law of nations." Report on Powers of the President 1.

33. See $i d$. at 6.

34. See Corwin, The President: Office and Powers 131 (2d ed. 1941). The Steel Seizure case (Youngstown Sheet \& Tube Co. v. Sawyer, 343 U.S. 579 (1952)) sheds little light on this question. One of the arguments apparently made by the Government to support the seizure was its "inherent power . . supported by the Constitution, by historical precedent and by court decisions." Id. at 584. It is not clear, however, whether this argument relied upon the doctrine of inherent powers in its technical sense: in summarizing the Government's position, the Court made reference merely to the distinction between "express" and "implied" powers. Id. at 587. The term "inherent" may have been used only in the latter sense.

35. McClure, International Executive Agreements 321 (1941).

36. See Rossiter, The Supreane Court and the Comnander in Chief 78-79 (1951). 
action would be beyond his powers. ${ }^{37}$ Certainly there are political considerations which normally would cause a President to hesitate long before testing this power. But the conclusion of an agreement of peace is one technique by which the exercise of military force may be terminated, and as such it can perhaps be regarded as a natural incident of the President's power as Commander in Chief. An attempt to make peace by agreement would be less radical than at first it seems, for the power to make peace appears in reality to be a composite of a variety of other powers, most of which the President has exercised. Furthermore, it is certain that the President has power to conclude agreements preparatory to the drafting of peace treaties, as for example the Moscow Agreement of December 1945, dealing with the preparation of treaties with Italy, Finland, Rumania, Bulgaria, and Hungary, establishing a Far Eastern Commission and Allied Council for Japan, and providing for the reestablishment of Korea as an independent state. ${ }^{38}$ And finally, the Supreme Court has stated that war may be terminated by various methods, including "Presidential proclamation."

On several occasions the President has exercised his authority as Commander in Chief to make international arrangements regarding the control of military equipment and resources. By multilateral agreement in 1945 the United States joined other governments both in approving the retention of international control over the merchant shipping of the signatory nations for as long after World War II as might prove necessary, and in establishing an international authority to regulate the use of this shipping. ${ }^{40}$ Similarly, in 1945 the United States, Canada, and the United Kingdom issued a joint statement signed at Washington, affirming the desirability of exchanging information regarding the use of atomic energy for peaceful purposes, and recommending the establishment of a United Nations commission to study the means of controlling it in war." To a like effect was the secret 1943 agreement between the United States and Great Britain regarding military and industrial use of atomic energy.

A familiar exercise of the Commander in Chief power has been the conclusion of armistice agreements with defeated enemies. Perhaps the first use of this power was the agreement terminating the Spanish-American War.42 During World War II a number of armistice and similar agreements were concluded by the President. The Commander in Chief clause was the constitutional

37. This President was Wilson. Id. at $79 \& \mathrm{n} .23$.

38. Moscow Agreement, Dec. 27, 1945, 60 Stat. 1899, T.I.A.S. No. 1555.

39. Ludecke v. Watkins, 335 U.S. 160, 168-69 (1948) (dictum).

40. Principles Faving Reference to Continuance of Coordinated Contrul, Aug. 5, 194, T.I.A.S. No. 1722.

41. Atomic Energy: Agreed Declaration, Nov. 15, 1945, 60 Stat. 1479 (1946), T.I.A.S. No. 1504.

42. This agreernent by virtue of its provisions for the relinquishment of Spanish claims to Cuba and for the cession of Puerto Rico by Spain to the United States eame

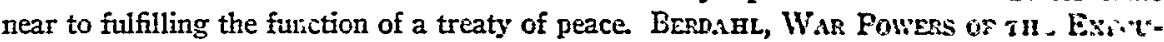
Tive ix The Uxited STATEs 234 (1920). It also supports the proposition that the Cummander in Chief may presently possess most of the powers nccessary to conclude truatiof peace in the unlikely event that it should ever become necessary. 
basis for American participation in the agreement concluded by the United Nations approving the principles of the Atlantic Charter and pledging the signatory nations not to conclude separate armistice agreements with the enemy. ${ }^{43}$ In accordance with this agreement, the Allied Commander in Chief presented to Italy in $1943^{44}$ the armistice agreement which was operative until terminated by the Treaty of Peace signed in Paris in 1947.45 So also the Allied Supreme Commanders accepted the German surrender ${ }^{46}$ and the surrender of Japan. ${ }^{47}$ The most recent exercise of this power is, of course, the conclusion of the armistice in Korea. ${ }^{48}$

Under the Commander in Chief power the President has repeatedly made international agreements regarding the administration of liberated or conquered territory in the aftermath of war. A recent agreement restored liberated Norwegian territory to the control of the Norwegian Government as rapidly as possible consistent with the military needs of the Allied forces. ${ }^{40}$ World War II also provides numerous examples of agreements concluded by the President regarding the control of conquered territory..$^{30}$ Thus at Berlin in June 1945, the United States joined with Russia, the United Kingdom, and the Provisional Government of France in a general agreement with respect to the defeat of Germany and the assumption of control over occupied German territory. ${ }^{\text {b1 }}$ Four years later the tripartite administration of Western Germany was terminated by an agreement which merged the three Western Zones, established the High Commission for Germany, and drafted the Occupation Statute to serve as fundamental law for the Western Zone. ${ }^{52}$ And economic integration

43. Cooperative War Effort, Jan. 1, 1942, 55 Stat. 1600, E.A.S. No. 236.

44. Armistice With Italy, Sep. 3, 1943, 61 Stat. 2740 (1947), T.I.A.S. No. 1604.

45. Peace Treaty With Italy, Feb. 10, 1947, 61 Stat. 1245, T.I.A.S. No. 1648; Armistice with Rumania, Sept. 12, 1944, 59 Srat. 1712 (1945), E.A.S. No. 490; Armistice With Bulgaria, Oct. 28, 1944, 58 Star. 1498, E.A.S. No. 437; Armistice With Fungary, Jan. 20, 1945, 59 Stat. 1321, E.A.S. No. 456.

46. German Surrender Agreement, May 7, 1945, 59 StAт. 1857, E.A.S. No. 502.

47. Japan Surrender Agreement, Sept. 2, 1945, 59 STAт. 1733, E.A.S. No. 493.

48. Korean Armistice Declaration, July 27, 1953, T.I.A.S. No. 2782.

49. Restoration of Norwegian Territory Agreement, May 16, 1944, T.I.A.S. No. 1514.

50. For a brief discussion indicating that the President's broad and almost excclusive control over conquered territory has been recognized by the Supreme Court in connection with earlier wars, see Rosstter, The Supreme Court and the Commander in Cuiev, 120-25 (1951).

51. Declaration Regarding Germany, June 5, 1945, 60 STAт. 1649 (1946), T.I.A.S. No. 1520. At the same time all four powers issued supplementary statements regarding administrative arrangements for the occupation, the zones agreed to be occupied by cach, and the means established for consultation with the other United Nations.

52. Merger of Three Western German Occupation Zones, Apr. 8, 1949, T.I.A.S. No. 2066. It was in pursuance of this agreement that the President by executive order established the office of United States High Commissioner for Germany. Exec. Order No. 10062, 14 F. R. 2965 (1949).

Similar agreements have dealt with other post war administrative problems. Provisional Administration of Venezia Giulia Agreement, Jun. 9, 1945, 59 Stat. 1855, E.A.S. No. 501 (including Trieste); Occupation of Austria Agreement, July 9, 1945, 61 STAx. 
of the Western Zones of Germany was the subject of two agreements entered into by the United States on the sole authority of the President. A memorandum signed by the United States and Great Britain concerned the economic coordination of the American and British zones; ${ }^{63}$ it was terminated in accordance with its terms by the subsequent merger of the three Western Zones. The second agreement, effected by an exchange of notes with France in mid1947, regulated coal exports from the Western Zones of Germany. Th This agreement, subject to revision at the end of 1947 , was continued informally until the serious coal shortage in Europe came to an end in 1949.55 Thus, our experience indicates that the broad power of the Commander in Chief to administer occupied territory must frequently be exercised through the medium of Presidential agreements and that power to make effective agreements continues until the conclusion of a treaty of peace with the government of the occupied territory.

A famous example of the exercise of the Commander in Chief power is the agreement concluded in 1817 with Great Britain, limiting armament of the Great Lakes. ${ }^{56}$ After six months this agreement was submitted to the Senate and approved as a treaty. But at the time it was concluded its sole basis appears to have been the independent power of the President as Commander in Chief. And even after the Senate acted, a ratification was never made or exchanged with Great Britain, although an executive ratification is generally recognized as a prerequisite to the legal effectiveness of a treaty. 57

A common non-military exercise of the President's power as Commander in Chief is his disposition of financial claims of allied and hostile powers. In 1944, the United States and Great Britain concluded an agreement allocating damage claims arising out of the war to claims commissions of the two countries for settlement. ${ }^{5 s}$ The United States and the United Kingdom also ex-

2679 (1947), T.I.A.S. No. 1600; Reestablishment of Austrian Government Agrcement, June 28, 1946, T.I.A.S. No. 2097; Agreement Seating United States Representative on Central Commission of the Rhine, Oct. 4, 29, \& Nov. 5, 1945, 50 Srar. 1932 (1946), T.I.A.S. No. 1571; Agreement Terminating the Berlin. Blockade, May 4, 1949, T.I.A.S. No. 1915.

53. Agreement on Fusion of American and British Occupation Zones, Dec. 2, 1946, 61 StAT. 2475 (1947), T.I.A.S. No. 1575.

54. German Coal Export Agreement, Apr. 19, 1947, T.I.A.S. No. 2109.

55. Closely related to the agreements regarding the administration of conquered territory are those reestablishing normal conditions in foreign nations following war. See, e.g., European Coal Organization Agreement, Jan. 4, 1946, 00 Srat. 1517, T.I.A.S. No. 1508; European Transport Organizations Agreement, Sept. 27, 1945, 59 Srat. 1740, E.A.S. No. 494, pursuant to prior agreement with regard to the same subject, European Transport Agreement, May 8, 1945, 59 Stat. 1359, E.A.S. No. 458.

56. See H.R. Doc. No. 471, 56th Cong., 1st Sess. (1900).

57. See MacDougal \& Lans, Trcatics and Congressional-Executie' or Presidential Agreements: Interchangeable Instruments of National Policy, 54 YALE LJ. 181, 209 (1945).

58. Claims Arising From Armed Forces Personnel Acts, Feb. 29 \& Mar. 28, 1944, 61 Stat. 2728 (1947), T.I.A.S. No. 1602. 
changed notes regarding the disposition of captured United Nations vessels recovered during the course of the European liberation. ${ }^{50}$ And in 1947 the United States and Czechoslovakia reached agreement concerning the settlement of claims held by the two countries against each other as a consequence of the American occupation. ${ }^{\circ 0}$ By a number of presidential agreements the United States has waived claims it held against other nations. Thus by an exchange of notes the United States and Canada agreed to waive all claims for damages arising out of traffic accidents in which government vehicles were involved..$^{01}$ In 1946 the United States and Luxemburg mutually agreed to waive certain claims arising out of the conduct of the war. ${ }^{62}$ And in the following year the United States and the United Kingdom agreed to "forebear from asserting claims" against each other for injury to military property or personnel. ${ }^{\text {13 }}$ Finally, presidential agreements have been employed to settle reparation claims against aggressor nations. Thus, following World War II, the United States by multilateral agreement assented to the allocation scheme for reparation payments due from Germany and approved the establishment of an InterAllied Reparations Agency. ${ }^{64}$ Later this country joined France, the United Kingdom, Czechoslovakia, and Yugoslavia in establishing a plan for the allocation of a portion of these reparation payments to aid in rehabilitating certain non-repatriatable victims of the war..$^{65}$

\section{Wartime Agreements with Postwar Consequences: Yalta}

That the Commander in Chief clause authorizes the President to enter into agreements necessary to the conduct of a war has never been doubted. Most of these are concluded by the President's subordinates and are entirely routine in character. But occasionally an agreement of far-reaching consequences is

59. Agreement on Recaptured Vessels, May 7 \& June 15, 1945, 60 StAT. 1909 (1946), T.I.A.S. No. 1556.

60. Agreement on Claims Incident to Operations of the United States Army in Czechoslovakia, July 25, 1947, T.I.A.S. No. 1675.

61. Agreement on Traffic Accidents Involving United States and Canadian Armed Forces Vehicles, Mar. 1 \& 23, 1944, 60 Stat. 1948 (1946), T.I.A.S. No. 1581. This agreement specifically reserved all private claims. Two years later the United States atud Canada agreed to waive maritime claims. Agreement on Claims Involving United States and Canadian Vessels, Sept. 28, Nov. 13 \& 15, 1946, 61 Stat. 2520 (1947), T.I.A.S. No. 1582 .

- 62. Agreement on Waiver of Certain Claims Between the United States and Luxemburg, Sept. 12, 1946, T.I.A.S. No. 2067.

63. Agreement Between United States and Great Britain on Claims Resulting From Armed Forces Personnel Acts, Oct. 23, 1946 \& Jan. 23, 1947, 61 Star. 2876 (1947), T.I.A.S. No. 1622. This agreement constituted a modification of a prior agrecment. Claims Arising From Armed Forces Personnel Acts, Feb. $29 \&$ Mar. 28, 1944, 61 StAT. 2728 (1947), T.I.A.S. No. 1602.

64. Agreement on German Reparations, Jan. 14, 1946, 61 Stat. 3157 (1947), T.I.A.S. No. 1655.

65. Agreement and Allocating Repatriation Payments, June 14, 1946, 61 STAT. 3157 (1947), T.I.A.S. No. 1594. 
made. Such was the Yalta agreement. ${ }^{66}$ When its terms became known it precipitated a controversy which continues still. In exchange for an undertaking by Marshal Stalin that Russia would conclude a pact of friendship with China and assist that country to extricate itself from Japanese control, and for his further undertaking that Russia would enter the Pacific War two or three months after Germany surrendered, the Prime Minister and the President pledged their countries' support to allot to Russia the Kuriles, the southern half of Sakhalin Island, and adjacent islands; to permit Russia to lease Port Arthur as a naval base; to internationalize the port of Dairen; and to permit Russia to operate the Manchurian Railroad jointly with China. Where the interests of China were affected by this agreement, President Roosevelt agreed to obtain the consent of the Chinese Government.

As a wartime military agreement designed to enlist Russia as an ally in the Pacific War, no dispute arises regarding the validity of the Yalta agreement. But its critics see it as more than a wartime military agreement. They argue that, while valid when formulated as an exercise of the Commander in Chief power, it should have been submitted to the Senate as a treaty after the war was over. Alternatively, they maintain that despite its purportedly military nature, it was in fact of far broader scope, and as such beyond the President's powers as Commander in Chief. The first criticism is supported by certain statements made by President Roosevelt at the Yalta meeting and afterwards, indicating his recognition of the necessity to sulmit the agreement to the Sonate for subsequent approval. ${ }^{67}$ And as a political matter it might have been desirable to obtain Senate approval after secrecy ceased to be of importance. But since the President purported to bind the United States as of the time he signed, despite any later collateral statements, failure of the Senate to approve the agreement would not affect its international validity. Morenver, if the agreement was valid at the time it was entered into, any Senate action coming after it was made public would have been mere formality, for by then many of the concessions were faits accomplis. In this respect the Yalta agreement differs from the secret agreement between Churchill and Roosevelt regarding military use of atomic energy. As an agreement of continuing effect, the latter might have been terminated at any time (as in fact it appears to have been by the Atomic Energy Act of 1946), so that submission to the Senate for approval would have been meaningful.

There is somewhat more consistency, though little cogency, in the argument that the Yalta agreement was invalid ab initio because it was beyond the scope of the Commander in Chief power. This argument is shored up in several ways: the extreme informality of the document is alleged to indicate that the

66. Yalta Agreement, Feb. 11, 1945, 59 STAт. 1823, E.A.S. No. 498.

67. For the text of the President's report to Congress on the Yalta meeting and for Byrnes' account of the President's statement at Yalta, see Par, Legal Aspecls of the Yalta Agreentent, 46 Axs. J. INT'L L. 40, 43 -(1952), and Briggs, Edilorial Comment, 40 Asr. J. INT'L L. 376, 380 (1946). 
agreement was intended to be personal to the signatories; ${ }^{\mathbf{6 8}}$ a state is supposed to be unable to make a binding agreement affecting the interests of other states without their consent; 99 the above-mentioned statements by Roosevelt and some by Byrnes are said to indicate that the agreement required Senatorial approval; and the agreement is alleged to violate various prior treaties. ${ }^{70}$ There would seem to be little merit in the first contention, inasmuch as no particular formalities are required for an agreement to be binding at international law, and there is no indication of an intent that the agreement should have such limited effect. ${ }^{11}$ The second argument has no relevance to the question of constitutionality; furthermore, President Roosevelt did subsequently obtain the consent of China, thus apparently satisfying any defect in the agreement as made. The facts on which the third argument is based have never been made entirely clear; moreover, whatever statements were made by Byrnes and Roosevelt, they are not necessarily inconsistent with the immediate wartime validity of the agreement under the Commander in Chief power. The fourth contention is unpersuasive in view of the fact that there is consiclerable support for the proposition that in terms of constitutional law a Presidential agreement may supersede contrary provisions of prior treaties. ${ }^{\mathbf{2}}$

The stronger position would thus seem to be that the agreement made at Yalta was a valid exercise of the President's power as Commander in Chief. Insofar as its purpose was to expedite the war in the Pacific it is free from question. And the various commitments made to Russia, read as subject to the condition, subsequently satisfied, of obtaining the assent of China, seem equally permissible. Other Presidential agreements have transferred the ownership of territory: for example, an agreement transferred Puerto Rico to the United States and deprived Spain of her claim to Cuba. ${ }^{73}$ Historically, the President's power as Commander in Chief has been very broadly construed when necessary. At the time the Yalta agreement was concluded military need, rightly or wrongly, was believed to justify the concessions made. The major objection to the Yalta agreement has obviously been political rather than legal. There has always been a strong feeling, based on sound considerations of policy, that far-reaching agreements determining American foreign policy should, as a practical matter, receive the approval of the legislative branch of government whenever possible. But the fate of the so-called Yalta Resolution in Congress would seem to indicate that subsequent political protest is not the proper measure of legal validity of a presidential agreement. ${ }^{74}$

68. Par, stipra note 67 , at 43,50 ; Briggs, supra note 67 , at 380,382 .

69. Par, stipra note 67 , at 51 .

70. Id. at 51-54.

71. Legal Status of Eastern Greenland, P.C.I.J., Ser. A/B, No. 53, at 22-147 (Judgment 1933).

72. See text at note 154 infra.

73. See note 42 supra.

74. Despite much demand by individual Congressmen for an unequivocal repudiation of the secret wartime agreements, the draft resolution submitted by President Eiscnhower in February 1953 merely accused the Soviet Union of "perverting" the agreements "in 


\section{Power to Commit Military Resources Abroad}

One of the most controversial facets of the President's authority as Commander in Chief is his power to commit the armed forces without a congressional declaration of war. Although this power, by its nature, is oiten exercised by other means than international agreements, in several important instances the President has entered into agreements committing our military resources abroad. It is evident that this use of the Commander in Chief power might be substantially curtailed if the President is unable to conclude such agreements. And the scope of his power to make international agreements in this context can best be measured by the substantive exercises of the Commander in Chief power to commit the armed forces.

Ever since 1787, it has been recognized that the President possesses the power to meet military emergencies by the use of force whether or not Congress has technically committed the nation to war. The existence of this power is apparent from the legislative history of the constitutional provision conferring upon Congress authority to "declare war."75 The original draft of this provision gave Congress power to "make" rather than "declare" war;" but the provision was amended to its present form in order, as Madison's notes record the tenor of discussion, to "leave to the Executive the power to repel sudden attacks."'77 The practical necessity of rapid and decisive action to meet the swift onslaught of modern war, and the need for occasional isolated military action on a scale too small to justify declaration of war, indicate the wisdom of this provision. ${ }^{78}$ Consequently, over the courze of time the responsibility for initiating and conducting military action, even when a declaration of war is involved, has come to rest with the President. ${ }^{70}$ Invocation of the term "war" has been limited to a very few major military campaigns, ${ }^{80}$ while there have been numerous instances of a so-called "retail use of force" 81 carried out under the constitutional authority of the President alone.

violation of [their] clear intent." N.Y. Times, Feb. 21, 1953, p. 4, cols. 3-4. Secretary of State Dulles stated that "the declaration does not involve any actual repudiation of any" legally effective agreements." Rather, said Dulles, the draft declaration had two primary purposes: "One is to register dramatically what we believe to be the many breaches by the Soviet of the wartime understandings; and, secondly, to register equally dramatieally the desire and hope of the American people that the captive people shall be liberated." N.Y. Times, Feb. 19, 1953, p. 3, cols. 2-3. The entire issue of the validity of such agreements as Yalta was abandoned before the resolution reached a vote on the floor of Congress.

75. U.S. CoNsT. art. I, \& 8, cl. 11.

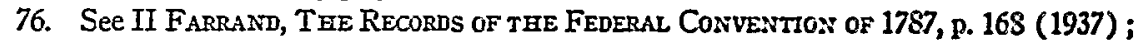
Douglas, The Constitutional and Legal Basis for the President's Action in Using Our Armed Forces to Repel the Invasion of South Korca, 96 CosG. REc. 9647 (1950).

77. Quoted in II FARRAND, op. cit. supra note 76, at 318.

78. See Douglas, sipra note 76, at 9648.

79. Even the struggle between Lincoln and his Congress which, insolar as control of the army was concerned was manifested in the activities of the Congressional Committee on the Conduct of the War, eventually resulted in a presidential victory.

80. See Rogers, World Polictng \& the Constitution 87 (1945).

81. See Douglas, supra note 76 , at 9648. 
But executive use of military force is not without limit: the President may use force only to protect the interests of the United States or the rights of its citizens. ${ }^{82}$ Within these broad bounds, military action has been taken for at variety of reasons, some of which deserve particular mention.

Protection of the honor of the United States has caused the President to call out the armed forces. President Buchanan, without congressional authorization, ordered a naval attack on Cantonese forts for the stated purpose of avenging an insult to the flag of the United States. ${ }^{83}$ And President Wilson ordered the capture of Vera Cruz-an act later approved by Congress-for the same purpose. It is, of course, not difficult to find in the background more fundamental political motivations.

Military force has often been employed by the President to protect the property or lives of American citizens abroad. In at least one instance the courts have approved the President's authority to use the armed forces for this purpose without congressional assent. ${ }^{84}$ Indeed, the power has become so well established through repeated exercise that "some people have been misled into thinking that the protection of American rights abroad is almost the only justification for the use of troops abroad in the absence of organized hostilities, and without the specific authority of Congress." 85

On a number of occasions the President has employed the Commander in Chief power for the completely nondefensive purpose of aiding the development of commercial relations. The use of American troops in the Boxer Rebellion in 1890 was partly justified on the ground of protecting the lives of American citizens in China, but was largely motivated by the desire to secure peace in China for the sake of commercial development. ${ }^{86}$ So also the lengthy foreign intervention known as the "opening up" of Japan was conducted without congressional authorization, from the first visit by Commodore Perry in 1853 to the international naval bombardment of Shimoneseki in 1863, in which the United States was a participant. ${ }^{87}$

On several occasions Presidents have used force, without specific congressional approval, to carry out the objectives of treaties. ${ }^{88}$ Theodore Roosevelt sent troops to Cuba to queil revolution, under the authority of the Platt Amendment, which permitted the United States to intervene in Cuban affairs to

82. Report on Powers of the President 7.

83. See Berdahl, War Powers of the Executive in the United States 51 (1920).

84. Durand v. Hollins, 8 Fed. Cas. 111, No. 4186 (S.D.N.Y. 1860). See also In re Neagle, 135 U.S. 1, 63-64 (1890) ; Slaughter House Cases, 16 Wall. (83 U.S.) 36, 79 (1872) ; Perrin v. United States, 4 Ct. Cl. 543 (1868); and cases collected in the appendix to ROGERS, op. cit. supra note 80 .

85. Report on Powers of the Prestident 8.

86. Id. at 9.

87. Ibid.

88. A concurrent constitutional basis for such action is the provision obligating the President to see that the laws are executed. U.S. ConsT. art. II, $\S 3$. This has been recognized, ever since Marshall's speech in Congress in 1800, to include the power to exea cute the provisions of treaties. 
preserve independence and protect the Cuban government. Congress appropriated the necessary funds but never acted directly to approve the President's action. And President Cleveland sent troops to Panama in 1885 for the ostensible purpose of preserving Colombian sovereignty under a treaty with that country. ${ }^{89}$ Neither of these treaties specifically authorized the President to employ force in its execution.

A distinct, and unquestionably the most important, occasion for presidential use of force is the defense of the United States against actual or imminent attack upon its territory or that of its allies. The dispute concerning the scope of the President's constitutional power focuses here. The disagreement concerns, not the existence of the power, but rather the various factual circumstances which permit its exercise. In the Prizc Cases ${ }^{00}$ the Supreme Court upheld the power of the President to use force to defend the Union against Confederate attack despite the fact that no "war" had technically been declared by Congress. And it defined the most obvious of the factual situations in which the President may exercise his power: "If a war be made by invasion of a foreign nation, the President is not only authorized but bound to resist force by force. He does not initiate the war, but is bound to accept the challenge without waiting for any special legislative authority."01

These circumstances have, happily, been very rare in the history of the United States, and with the exception of the Civil War and perhaps certain incidents during the War of 1812 "invasion" has usually been more in the nature of a nuisance. This was the case, for example, when in 1818 General Jackson was sent into Florida, then a Spanish possession, to subdue Indians who had been raiding the border.92

But the constitutional power of the President to take military action in defense of the United States extends far beyond cases of actual invasion. An early example is the action of President Polk in 1845 in sending American troops into the territory of Texas, which was not then a part of the United States. ${ }^{93}$ A report prepared by the Executive in 1951 to answer doubts that the President had power to send forces to Europe in implementation of the North Atlantic Treaty ${ }^{94}$ pointed to numerous occasions when troops have been stationed abroad as a defensive measure, in the absence of any actual attack upon American territory or citizens abroad, and on the sole authority of the President. By exchange of messages between President Roosevelt and the Prime Minister of Iceland in July $1941^{\text {os }}$ the United States undertook to defend Iceland from attack, in return for the right to station American forces

89. Report on Powers of the President 11-13.

90. The Prize Cases, 2 Black (67 U.S.) 635 (1862).

91. Id. at 668 .

92. BERDAHL, op. cit. supra note 83 , at 65-67.

93. Report on Powers of the President 10.

94. See note 11 supra.

95. Defense of Iceland By United States Forces, July 1, 1941, 55 StAт. 1547, E.A.S. No. 232. 
in that country. Similarly, in 1941 the United States by presidential agreement recognized the sovereignty of Denmark over Greenland and undertook to assist Greenland in preserving that status. ${ }^{96}$ So also in 1947 the United States exchanged notes with Guatemala and China affirming the consent of those countries to the presence of American troops within their territories. ${ }^{07}$ It has thus been consistently recognized that the President possesses constitutional authority to implement national policy by stationing American troops abroad where their presence will contribute to the defense of the United States, even though they are not employed to repel an already attacking enemy.

Preventive agreements by the Commander in Chief need not, of course, involve sending troops abroad. By an exchange of notes in 1940 the United States gave destroyers to Great Britain in return for a ninety-nine year lease of various naval and air bases in the Western Hemisphere.98 The ensting controversy did not raise the question whether the President's action was within his independent power as a matter of constitutional law. Rather, the major conflict of opinion involved the question whether the agreement was consistent with the international status of the United States in 1940, and whether it contravened certain prior statutory provisions. ${ }^{00}$

A different sort of objection has been raised to general statements of policy with respect to national security which the President has issued from time to time on his own motion, as in the case of the Monroe Doctrine, or jointly

96. Defense of Greenland, April 9, 1941, 55 Star. 1245, E.A.S. No. 204. The agreement was concluded between the United States and Denmark. Criticism of its validity is not based upon the ground that the President lacked constitutional power to make it, but rather on the argument that the other party to the agreement was without authority to sign it. See Briggs, The Validity of the Greenland Agreement, 35 Ax. J. INT'L L. 506 (1941).

97. United States Armed Forces in Guatamala, Aug. 29, 1947, T.I.A.S. No. 1663, and United States Armed Forces in China, Sept. 3, 1947, 61 Stat. 3755, T.I.A.S. No. 1715. The agreements were made in order to comply with the resolution of the United Nations General Assembly requesting member nations to withdraw troops stationed in the territory of any other member without the consent of the latter.

98. Naval and Air Bases Treaty with Great Britain, Sept. 2, 1940, 54 STAT. 2405, E.A.S. No. 181. Subsequently, the two countries entered into a supplementary agreement with respect to the status of Newfoundland. Agreement with Great Britain on Leascd Naval and Air Bases, Mar. 27, 1941, 55 STAT. 1560, E.A.S. No. 235.

99. The constitutional issue is not even raised by perhaps the most vigorous critic of the agreement. See Briggs, Neglected Aspects of the Destroyer Deal, 34 AM. J. INT'L L. 569 (1940). Another critic believes that such a presidential agreement, even in the absence of contrary legislation, would be invalid; but the basis of his argument appears to be only a general conviction that no important international agreement should ever be concluded by the President alone. He offers no firmer support for this opinion than certain "constitutional understandings." Borchard, The Attorney General's Opinion on the Exchange of Destroyers for Naval Bases, 34 Ax. J. INT'L L. 690 (1940). For the vicw that, in the absence of legislation to the contrary, such a transaction is properly the subject of presidential agreement, see Wright, The Transfer of Destroyers to Grcat Britain, 34 Ard. J. INT'L L. 680 (1940), and Attorney General Jackson's statement, Acquisition of Naval and Air Bases in Exchange for Over-Age Destroyers, 39 Ors. Atr'y GEN، 484 (1940). 
with other nations as in the Act of Chapultepec. ${ }^{100}$ In the latter pronouncement the American Republics mutually recognized the desirability of uniting to keep peace and meet aggression, and recommended the conclusion of a treaty to provide methods to achieve these purposes. A recent mutual security statement issued under the independent authority of the President is, of course, the Joint Policy Declaration Concerning the Korean Armistice, ${ }^{101}$ in which those United Nations members participating in the Korean campaign pledged their readiness to rejoin forces to resist new aggression. It has been suggested that these general statements of policy, made in a time of no immediate danger, do not of themselves afford a sufficient basis for the subsequent use of force by the President. ${ }^{102}$ But such anticipatory identifications of national interest might be said to make at least a presumptive case for the reasonableness of presidential action.

Thus far, in investigating the substantive exercises of the Commander in Chief's power to commit the armed forces, in order to ascertain the areas in which he may find it necessary independently to conclude agreements, we have seen that: the President has a recognized independent constitutional authority to repel an actual attack directly upon the territory of the United States; he may use force abroad where American interests are directly in question; and he may station troops abroad and enter into various other military arrangements as a preventive measure. But the extent of his power is less certain in the event of an actual attack with only "indirect" effect on American interests. This demand for a "direct" American interest is a natural consequence of the apprehension that the Commander in Chief power may be abused. Situations can be imagined in which the force of public opinion would prove an insufficient safeguard, and it is difficult to withdraw from a military campaign once undertaken, whatever counterbalancing control Congress may possess over the pursestrings of the army.

The controversy evoked by American participation in the Korean conflict illustrates the confusion and the possible perils resulting from use of the outmoded concept of what is a direct effect on American interests. Although it was said that "the constitutional powers of the President were exceeded and the constitutional powers of the Congress of the United States were bypassed" by our military action in Korea, ${ }^{103}$ the action of the President seems well within his independent authority. ${ }^{10 x}$ Today the interests of one nation are often

100. Inter-American Conference on Problems of War and Peace, Mar. \&, 1945, 60 Stat. 1831, T.I.A.S. No. 1543. This agreement was the forerunner of the Inter-American Treaty of Reciprocal Assistance, Sept. 2, 1947, 62 STAт. 16S1, T.I.A.S. No. 1838.

101. Korean Armistice Declaration, July 27, 1953, T.I.A.S. No. 2781.

102. Wright, Constitutional Procedure in the United States for Corrying Out Obl:gations for Military Sanctions, 38 Axr. J. INT's L. 678, 682 (1944).

103. Statement of A. J. Schweppe, Hearings before Subcommittce of Setale Committee on the Judiciary on S.J. Res. 1 \& S.J. Res. 43, 83d Cong., 1st sess. 62 (1953).

104. "The decision of the President to aid South Korea was, therefore, both in the best interests of the United States and in no sense violated Constitutional thcory or prac. tice. It was, instead, a sound measure to guard against an ultimate and indirect threat 
affected by acts occurring half a world away: "directness" of interest is no longer a function of geographical propinquity. The concern of the United States in Korea was indirect only in the sense that the danger posed by the invasion of South Korea might not culminate in actual physical attack upon the territory of the United States until some distant time. In every other sense it affected American interests in the most direct manner possible.

The action of the President in the Korean conflict may also be justified on the ground that the United Nations Charter, which was ratified by the Senate as a treaty, broadens his independent powers to use the armed forces. Secretary of State Dulles has recognized that the power of the President to take military action can be broadened by the ratification of a treaty; he stated that "one result of the North Atlantic Treaty is to enlarge somewhat the area within which the President can make war, as against the so-called declaration of war."105 Such a delegation of authority to the President by treaty does no violence to the concept of separation of powers. It has been consistently recognized that this concept applies in a different fashion to the conduct of foreign affairs: so that the Government may act as a single entity, Congress can delegate authority to the President that would not be constitutionally permissible in domestic matters. ${ }^{100}$ The treaty power of the Senate extends to all matters of international concern. Therefore, the Senate can enlarge the President's foreign affairs power by its ratification of a treaty. A common method of by-passing this constitutional question has been to argue that the effect of the treaty is not to increase the President's power, but merely to define more broadly the purposes for which he may properly employ it. In answer to the objection that the President's taking military action under the North Atlantic Treaty is unconstitutional, the argument would run like this: the Senate did not grant any new power but merely redefined the interests of

to the security of the United States." Douglas, The Constitutional and Legal Basis for the President's Action in using Our Armed Forces to Repel the Invasion of South Korca, 96 Cong. Rec. 9647 (1950).

105. Hearings, supra note 103 , at 887.

106. See text at notes 23-26 supra. But the courts have implied that there are constitutional limits to congressional delegation of foreign affairs power. Sce United States v. Curtiss-Wright Export Corp., 299 U.S. 304, 322 (1936) (dictum). A recent lower court case illustrates this proposition even more forcefully. In Colonial Airlines, Inc. v. Adams, 87 F. Supp. 242 (D.D.C. 1949), plaintiff challenged the constitutionality of that portion of the Civil Aeronautics Act of 1938, 52 StAr. 991 (1938), as amended, 49 U.S.C. $\$ \$ 482(\mathrm{~b})$, 601 (1952), which authorizes the Civil Aeronautics Board to recommend to the President the issuance of a permit to a foreign air carrier to make scheduled flights into the United States. A majority of the three-judge district court held the delegation constitutional, on the ground that the standards provided in the act to guide the Board's discretion werc adequate, since the delegated power related to foreign affairs. Judge Goldsborough dissented on the ground that, although the standards provided to guide the Board were sufficient, the Act did not require the President, in approving or disapproving the Board's recommendation, to observe any standards; the delegation was consequently unconstitutional. Thus, both majority and dissent recognized the necessity for sufficient standards in a delegation of foreign affairs power. 
the United States, in defense of which the Commander in Chief power may be exercised, to include considerations of mutual security which might otherwise be regarded as too remote. As a matter of fact, it seems likely that the President already possesses all the authority which the North Atlantic Treaty requires him to exercise. Furthermore, this extremely technical distinction between the scope of the President's authority and the scope of the objective for which he may exercise his authority has little meaning. Though it may afford a useful means to rationalize authority for presidential action in a specific case, it is in fact a recognition of broad power.

Constitutional history has shown that the President can take military action under his independent powers whenever the interests of the United States so require. In the modern world the scope of America's interest can be determined only by reference to the state of affairs in the international arena as a whole and to the over-all purposes of our foreign policy. Any rigid test of protectable interest would leave the nation dangerously unequipped for survival. On the other hand, the President may not take military action where the interests of the United States are not involved. In the absence of crisis he should defer to the legislature. He is limited here by his own good faith, by the impeachment power of Congress, and by numerous important political considerations, such as the necessity of retaining congressional cooperation and the advisability of permitting military policy to be guided to some extent by public opinion. If these safeguards seem insufficient, it must be remembered that there is no feasible alternative. The circumstances calling forth the exercise of the Commander in Chief power cannot by their nature be anticipated. The same reasons which have given the President as Commander in Chief the power to meet all international crises require that he have at his disposal all the available techniques for implementing this power. Since, as we have seen, agreement-making is often an essential technique, the President's ability independently to conclude international agreements must be coextensive with his substantive powers as Commander in Chief. ${ }^{10 \pi}$

\section{Power to Receive Representatives of Forcign Govermmenls}

In contrast to the many international agreements which have been concluded under the authority of the President as Commander in Chief, there have been

107. It should be noted that the President is not limited in the use of force to the authority which he possesses as Commander in Chief. As the initiator of American foreign policy, he often determines the interests of the United States which the Constitution permits him to defend. Thus the use of force to protect these interests is in effcet supported by his authority as Chief Executive. Furthermore, his constitutional duty to execute the laws has been construed to include the law of nations. See text at notes 118-30 infra. And it has been said that "there exists today something in the nature of an internstional common law by which aggressive war is made illegal." Schwarzer \& Wood, Presidential Power and Aggression Abroad: A Coustitutional Dilenma, 40 A.B.A.J. 394,395 (1954) (citing in support of this proposition the Kellogg-Eriand Pact, the WWar Crimes Trials, and the provision for international policing under U.N. CEARTER art 43). If this be so, his constitutional duty to execute the laws may afford the President an additional authorization for the use of force abroad. 
very few such agreements based upon his power to receive representatives of foreign governments. Nor is this surprising: receiving representatives and recognizing their governments are peculiarly unilateral acts, not often suited to the use of international agreements. Nonetheless, "there is an immense authority latent in his power of recognition," ${ }^{108}$ and if it is to be rationally implemented in many contexts it must include the power to make international agreements.

The President's discretion in the recognition of new governments and nationstates and of belligerent status is not limited by the powers of the other branches of government. ${ }^{109}$ The recognition power may be of determinative importance in foreign policy. President Wilson brought on the clownfall of the Fuerta government in Mexico in 1915 by refusal to recognize it. Similarly, the refusal of the United States to recognize the government of Communist China has been a key factor in the international policy of the entire Western World.

The President also has complete discretion to refuse to receive particular representatives of other governments, or to request the recall of foreign officials as a form of censure or retaliation. ${ }^{110}$ These techniques for restricting or severing diplomatic relations have long been orthodox instruments of foreign policy. And the President has established himself as the exclusive medium through which all communication addressed by the outside world to the United States is directed.111

Nothing, of course, prevents Congress from offering its advice to the President on matters of recognition or restrains the President from seeking it. For example, it was Congress which suggested to the President that he not seek to restore the Hawaiian monarchy by force, and, as one commentator remarks, by that action "probably saved the Administration from a fatal error."112 Furthermore, congressional recommendations, regardless of their soundness, often prove extremely useful to the President in reflecting public opinion.

\section{Obligation to See that the Laws are Executed}

The constitutional duty of the President to see that the laws are faithfully executed provides another basis for independent executive action. Although execution of the laws often does not require the conclusion of international agreements, such agreements may be essential to the fulfillment of this duty

108. Laski, The Amrercan Presidency 174-75 (1940).

109. "In every case, as it appears, of a new government and of belligerency, the question of recognition was determined solely by the Executive." 1 MOORE, DiG. INT'L L. 243. 44 (1906), quoted in Coriwin, The President's Control of Foreign Relations 72 (1917). See also The Divina Pastora, 4 Wheat. (17 U.S.) 52 (1819); United States v. Palmer, 3 Wheat. (16 U.S.) 610 (1818).

110. See Corwin, tre President's Control of Foreign Relations 46 (1917).

111. See id. at $48-49$, citing as a notorious departure from this rule the warning addressed by the German Government directly to the American people through the newspapers, cautioning them to stay out of the combat zones established during World War I.

112. See id. at 45 . 
in appropriate circumstances. Therefore the agreement-making technique must be as available to the President for the discharge of this obligation as for the implementation of his substantive powers. ${ }^{113}$

Several of the instances of the use of force abroad noted in the discussion of the Commander in Chief power might equally well be justified under this constitutional provision. ${ }^{114}$ Similarly, it has long been recognized that the President may enforce the provisions of treaties under the same constitutional authority..$^{115}$

The President's obligation to execute the "laws" may also require him to enforce the provisions of international agreements other than treaties, despite the argument that a strict construction of the supremacy clause of the Constitution ${ }^{116}$ might seem to qualify only treaties as "laws." It has been suggested that in using force to subdue the Boxer Rebellion the President was satisfying his constitutional duty to execute an agreement as much as he was exercising his Commander in Chief power. ${ }^{117}$

Finally, it has been persuasively maintained that the obligation to execute the laws includes a duty to execute the law of nations. This position was first set forth by Attorney General Wirt in 1822,118 and has received at least dictum support from the Supreme Court. ${ }^{119}$ The trial of World War II war criminals may be viewed as a Presidential execution of international law, ${ }^{120}$ for it is not at all clear that congressional legislation authorized all the functions of the International Military Tribunal. The charter of this tribunal, ${ }^{101}$ agreed

113. "Incident to the power to see that the laws are faithrully executed [the President] has power to enter into agreements with foreign countries neccssary to their enforcement." Statement by Judge Parker, Hcarings, supra note 103, at 711-12.

114. See Corwin, The Prestoent: Office and Powers 167-70 (2d ed. 1941).

115. McClure, International Executive Agreenisnts 316-17 (1941).

116. U.S. CoNst. art. VI, ci. 2.

117. McDougal \& Lans, Treatics and Congressional-Executize or Presidential Agrecnents: Interchangeable Instruments of National Policy, 54 YALE L.J. 1S1, 248, 280-81 (1945).

118. Restoration of a Danish Slave, 1 Ops. ATT'Y GeN. 565, 570-71 (1822): "The President is the executive officer of the laws of the country; these laws are not mercly the Constitution, statutes, and treaties of the United States, but those general laws of nations which govern the intercourse between the United States and foreign nations ..... The United States, in taking the rank of a nation, must take with it the obligation to respect the rights of other nations. This obligation becomes one of the laws of the country; to the enforcement of which, the President, charged by his office with the execution of all our laws, and charged in a particular manner with the superintendence of our intercourse with foreign nations, is bound to look ...."

119. MIcDougal \& Lans, supra note 117, at 248; See In re Neagle, 135 U.S. 1, 64 (1890) (dictum). Also see McClure, International Executive Agresaremis, 317-19 (1941).

120. "The grant of power to the Congress [to define and punish offenses against the law of nations] does not necessarily preclude exercise of authority by the President." Hirota v. MIacArthur, 338 U.S. 197, 207 (1948) (concurring opinion of Mr. Justice Douglas).

121. Agreement for Prosecution of Major War Criminals, Aug. \&, 1945, 59 Srat. 1544, E.A.S. No. 472. 
to by the Executive in 1945, defined three kinds of crimes for which the major German war criminals were to be tried: violations of the "laws and customs of war" as established by international law; crimes against humanity; and crimes against peace. The first category was traditional, and included the murder of hostages and prisoners of war, "wanton destruction," and "devastation not justified by military necessity." The other two categories, however, were novel. The second included the enslavement or extermination of civilian populations, and persecution on racial, political, or religious grounds. The third category made criminal the waging of aggressive war.

Congress has authorized the President to establish military commissions for the trial of violations of the international laws of war. The Articles of War ${ }^{122}$ authorize the President to establish military commissions for the trial of persons who can be tried by military tribunals under the laws of war. The jurisdiction of such commissions appears to include not only offenses derived from the laws of war but also those created by congressional legislation. The Espionage Act of $1917^{123}$ recognizes use of military commissions. On the basis of these statutes the Supreme Court concluded in Ex parte Quirin ${ }^{124}$ that the President acted validly in ordering trial by military commission for eight saboteurs who were captured after being landed by submarine on the East Coast in June 1942. And in passing on the military trial of General Yamashita ${ }^{125}$ for crimes committed in the Pacific War, the Supreme Court stated:

"[T] he order creating the commission for the trial of petitioner was authorized by military command, and was in complete conformity to the Act of Congress sanctioning the creation of such tribunals for the trial of offenses against the law of war ...."126

Even a dissenter to the result in that case admitted that authority for the trial stemmed from the constitutional power of Congress to "define and punish ... Offences against the Law of Nations." ${ }^{27}$ The language of the Court in these cases indicates that even in the absence of congressional authorization the President would have had power to order the trial of these criminals. If international law is the law of the land, and it is commonly agreed that it is, ${ }^{128}$ the President certainly has the authority and the duty to enforce it. One commentator has said, "Regardless of the manner or extent to which it may be implemented by national law, the law of nations is the

122. 41 Stat. $787-812$ (1920).

123. 40 Stat. 219 (1917), 50 U.S.C. § 38 (1952).

124. 317 U.S. 1 (1942).

125. In re Yamashita, 327 U.S. 1 (1946).

126. Id. at 11.

127. Id. at 26.

128. See Att'y Gen. Wirt's opinion, supra note 118. For a summary of various phascs of this subject, see Dickinson, The Laze of Nations as Part of the National Laze of the United States, 101. U. PA. L. REv. 26, 792 (1952-53). 
ultimate source of the authority to establish military tribunals to try offenses against the law of war."129

But the authority of the American representatives on the Nuremberg tribunal to sit on prosecutions for the second and third categories of crimes can best be traced to the power of the President. The crimes for which Congress authorized trial by military commission include only violations of the laws of war or supplementary congressional legislation. "Crimes against peace and humanity," although they represent a rational development of ancient doctrines of international law, have not been regarded as within any traditional definition of the laws of war. To the extent that the charter of the Nuremberg tribunal expanded the traditional laws of war it may be justified as an exercise of the President's authority as Commander in Chief. IVith this valid constitutional basis, the agreement became a part of international law which the President was obligated to execute as part of the law of the land. The bootstrap effect of combining these two constitutional provisions is subject to other constitutional and practical safeguards. ${ }^{130}$

\section{Power as Chief Executive}

The remaining constitutional source of the President's power in the field of foreign affairs is the provision authorizing him to act as Chief Executive. In a sense, this may be said to be the ultimate authority from which his power to make agreements arises. ${ }^{131}$ By virtue of this constitutional provision the President has always been recognized as the sole representative of the United States in conducting negotiations with other nations. ${ }^{132}$ This is the meaning of Jefferson's famous remark that the transaction of business with foreign nations is executive altogether. In addition to control over negotiations, the President as Chief Executive possesses a number of other broad powers, some of which by their nature may not often require implementation by international agreement.

The Chief Executive power may afford still another basis for the use of force abroad to protect American interests. ${ }^{133}$ Employment of force has frequently been in furtherance of general statements of United States policy, such as the Monroe Doctrine, which were promulgated under the authority of the President as Chief Executive. This was the case, for example, when Theodore Roosevelt acted after Senate delay to seize and administer the cus-

129. Cowles, Trial of War Criminals by Mrilitary Tribusals, 30 A.B.A.J. 330, 331 (1944).

130. See text at notes $158-65$ infra.

131. See 5 Hackworte, Digest of Int'L Law 402 (1943).

132. The exclusive power of the President to be the medium of communication to and from foreign nations is, of course, also established by the constitutional provision authorizing him to receive representatives from foreign governments. Sie test at note; 108-12 sttpra.

133. IIcDougal \& Lans, Treaties and Congressional-Exceutioue or Presidcutial Agrerments: Interchangeable Instruments of National Policy, 54 YAIE L.J. 181, 250 (1945). 
toms houses in Santo Domingo to prevent their being taken over by European creditors. ${ }^{134}$ Similarly, the Chief Executive power has been invoked to authorize the President to settle claims held by private citizens against other nations, ${ }^{135}$ and to grant commercial rights to foreign businesses.

The President and his high-ranking subordinates have frequently conferred with the heads of other governments on major issues of foreign policy, and have issued general statements which, although not purporting to possess binding force, give direction to the foreign policy of the United States. Several joint statements were issued during and after the recent World War. These are obviously within the Commander in Chief power, but insofar as they determine the broad outlines of American foreign policy in time of peace it would seem that they are also exercises of the President's power as Chief Executive. Among the more important recent statements of this type were the Atlantic Charter, ${ }^{136}$ outlining a general policy to be jointly followed by the United States and the United Kingdom in seeking to establish a durable peace, the declaration with respect to the use and control of atomic energy, ${ }^{137}$ the Yalta agreement, the Joint Policy Declaration Concerning the Korean Armistice, ${ }^{138}$ and the Moscow Agreement of $1945,{ }^{130}$ regarding the policies to be followed by the big three nations with respect to conditions in Southeastern Europe and the Far East. It is increasingly by means of such conferences and declarations that recent Presidents have set the course of American foreign policy. This exertion of Presidential control over foreign affairs seems readily justifiable under the power conferred on the President as Chief Executive.

\section{The Relative Scope of Independent Executive Agrecments}

Despite the fact that presidential agreements have been employed with greatly increased frequency in recent years, it has been forcefully argued that the power of the President to make international agreements is not as broad as the treaty power. Some of these arguments appear to rest upon no firmer basis than the circular proposition that, since the legal consequences of presidential agreements are more limited than those of treaties, the scope of agreements must be less than that of treaties. ${ }^{140}$ Whatever its rationale, a strong sentiment persists that presidential agreements are to some degree more limited in scope than treaties or congressional-executive agreements. ${ }^{141}$ The

134. See Corwin, The Constitution and World Organization 39 (1944); 5 HACKWORTH, op. cit. supra note 131, at 402-03.

135. McDougal \& Lans, supra note 133, at 249, 251, citing illustrations from the terms of John Adams and Jackson.

136. The Atlantic Charter, Aug. 14, 1941, 55 StAT. 1603, E.A.S. No. 236.

137. Atomic Energy Declaration by United States, United Kingdom, and Canada, Nov. 15, 1945, 60 Stat. 1479, T.I.A.S. No. 1504.

138. Korean Armistice Declaration, July 27, 1953, T.I.A.S. No. 2781.

139. Moscow Agreement, Dec. 27, 1945, 60 Stat. 1899, T.I.A.S. No. 1555.

140. See Borchard, Editorial Comment 39 An. J. INT'L L. 537, 538 (1945).

141. "We do not think that executive agreements should rise or were ever intended 
outer limits of the President's independent power to make agreements have never been clear. The present Secretary of State remarked in legislative hearings on the Bricker Amendment:

"It has long been recognized that difficulties exist in the determination as to which international agreements should be submitted to the Senate as treaties, which ones should be submitted to both Houses of the Congress, and which ones do not require any congressional approval ..... [I] $t$ would be extremely difficult, if not impossible, to fit all agreements into set categories .... [T] he Executive cannot surrender the freedom of action which is necessary for its operations in the foreign-affairs field." 142

Any attempt to define the difference between presidential agreements and treaties or congressional-executive agreements in terms of the subject matter to which such agreements properly extend must inevitably be unsatisfactory. There is no way to anticipate the necessities of foreign affairs with sufficient precision to permit an exact allocation of subject-matter between these various techniques. The controversy engendered by the proposed Bricher Amendment amply illustrates the difficulties and dangers of an effort to impose specific limitations in advance.

Attempt is sometimes made to determine the proper scope of the President's independent power to conclude international agreements by reference to the specific provisions of the Constitution. ${ }^{143}$ But the Constitution, as has been seen, is hopelessly vague as to the allocation of the foreign affairs power among the various branches of the Federal Government. And assuming that the intent of the Founding Fathers should be regarded as controlling, and that it could be determined with certainty on some problems, it is plainly impossible to determine how they intended to allocate power to deal with subjects which did not exist in their day.

The suggestion has been made that the President has no independent constitutional authority to conclude an international obligation which requires the exercise of congressional powers for its fulfillment. ${ }^{14 t}$ This proposed test

to rise to the dignity of treaties; . . . there is a legitimate area for executive agreements, but executive agreements should not be used to bypass the treaty powers ...." Statement by A. J. Schweppe, Hearings before a Subcommittee of the Senate Committer on the Judiciary on S.J. Res. 130, 82d Cong., 2 d sess. 44 (1952). Also see Lassi, The Aureriens: Presidency 177 (1940); Hyde, Constitutional Procedures for International Agrcancut by the United States, 31 PBoc. Axs. Soc'y INT'L L. 45, 52 (1937).

142. Statement by Secretary of State Dulles, Hcarings before Subcommitfce of Scratc Committee on the Jadiciary on SJ. Res. 1 \& S.J. Res. 43, 83d Cong., 1st sess. 65 (1953).

143. See, e.g., statements by Judge Phillips, Hcarings, supra note 142, at 996, and Schweppe, Hearings, supra note 141, at 43.

144. This was apparently the theory of Attorney General Jaclison in his opinion regarding the validity of the bases and destroyers exchange: "Some negotiations involve commitments as to the future which would carry an obligation to exercise powers vested in the Congress. Such Presidential arrangements are customarily submitted for ratifieation by a two-thirds vote of the Senate before the future legislative power of the country is committed." Acquisition of Naval and Air Bases in Exchange for Over-age Destroyers, 
raises several questions. In the first place, it is sometimes difficult to know whether the future exercise of congressional power required by an agreement forms a part of the international obligation or whether it relates merely to our effective utilization of the agreement. In the destroyer exchange a failure of Congress to appropriate money for the development of bases would not have affected the international obligation assumed by the United States, since the undertaking was completely discharged by the transfer. ${ }^{145} \mathrm{But}$ in the case of an international agreement to use military force the failure of Congress to appropriate funds might result in the inability of the United States to carry out its part of the agreement. If such indirect effect upon the fulfillment of the international obligation is intended to be within the scope of the suggested test, the test seems too broad. Its consequence would be to make impossible many kinds of action traditionally undertaken by the President under his independent powers, as well as by the President and the Senate under the treaty power, since in ultimate analysis most future commitments are likely to require at least an appropriation of funds by Congress for their fulfillment. ${ }^{146}$ Furthermore, in referring to the congressional participation required in order that the international agreement conform to American constitutional law, this principle constitutes, of course, not a criterion but a conclusion which assumes that certain subject-matters are beyond presidential power and exclusively within the competence of the whole Congress. The problem remains to determine what kinds of international agreements may be undertaken by treaty or by executive-congressional collaboration, as distinguished from those which may be concluded by the President alone. The "congressional action" test seems merely to restate the issue.

Of equally little utility is the suggestion that "legislative" matters may be undertaken only in the form of a treaty while "adjudicative" matters are proper subjects for an executive agreement. "Legislative" acts are customarily defined as those which establish general rules guiding the future course of conduct; "adjudicative" acts, on the other hand, purport only to dispose of a single immediate controversy upon its particular facts. Thus defined, it is evident that the vast majority of international agreements are "legislative," including a great number of presidential agreements whose constitutionality is scarcely open to question. ${ }^{147}$ A distinction between formulation and appli-

39 Ops. Atr'y Gen. 484, 487 (1940). See also Wright, Editorial Comment, 34 Ax. J. INT'L L. 680, 681 (1940).

145. See Wright, supra note 144 , at $681 \&$ n.7.

146. Insofar as this test states merely the desirable principle of cooperation between the legislative and executive branches of government, it is, of course, unexceptionable. It is presumably in this sense that another commentator has stid that: "The Executive would be acting improperly ... if he entered into an agreement imposing on the United States an obligation which he knew, or had reason to believe, to be unenforceable." Lissitzyn, The Legal Status of Executive Agreements on Air Transportation, $17 \mathrm{~J}$. A1k L. \& Comsr. 436, 443 (1950).

147. Perhaps armistice agreements, with their customarily detailed provisions governing the future conduct of the parties, provide one of the best illustrations. 
cation of policy can never be precisely drawn. Consequently, any attempt to impose a "legislative"-"adjudicative" dichotomy on the constitutional problem of agreements can only result in hopelessly confusing the issue.

During the course of the controversy regarding the proposed Bricker Amendment and its substitutes, it was often suggested that the proper test of the scope of presidential power in foreign affairs depends upon whether the agreement in question is "important" or "unimportant." All "important" agreements may only, according to this view, be made by treaty. Obviously this is imprecise language, which affords no basis for distinguishing one category from the other. The word "important" would appear to obscure a consideration of the extent to which the agreement in question constitutes a policy commitment on the part of the United States. Many agreements are either of so temporary a character, or relate to so minor a matter, that their role in the determination of foreign policy is negligible. Others are considerably more important in this respect. Traditionally, it is the Executive rather than the Legislature which is charged with the ultimate determination of the course of foreign policy, however much Congress may participate in an advisory capacity. But it does not follow that the broader the policy commitment involved, the clearer should be the President's right of e:iclusive determination of the issue. On the contrary, as the extent of commitment increases, the undesirability of unilateral decision becomes more apparent.

Traditionally, this problem of determining the limits of the President's independent power to make agreements has been cast in terms of the political theory of separation of powers. There is little question that the majur purpose of the draftsmen of the Constitution in trisecting the national grovernment was to protect private rights from infringement by tyrannical authority. ${ }^{148}$ Consequently, it is not surprising to find the concept worl ed out far more carefully in those provisions of the Constitution which relate to domestic affairs; in 1787 it was in this area that the principal threat to private liberties was anticipated. Today, even if it can be argued that there is an analogous risk resulting from the conduct of foreign affairs, the principle that no international agreement in contravention of constitutional rights can be valid, together with the sanctions, both legal and practical, by which this principle is enforced, should suffice to relieve all danger from this source. ${ }^{2+1}$

148. See Sharp, The Classical Anrerican Doctrine of the "Separation of Pencers," 2 U. CHI. L. REv. 385 (1935). Justice Brandeis said, in the course of his famous dissent in Myers v. United States, 272 U.S. 52, 293-95 (1926): "The doctrine of the separation of powers was adopted by the Convention of 1787 , not to promote efficiency but to preclude the exercise of arbitrary power. The purpose was, not to avoid friction, but, by means of the inevitable friction incident to the distribution of governmental powers among thrce departments, to save the people from autocracy .... In America, as in England, the conviction prevailed then that the people must look to representative assemblies for the protection of their liberties."

149. For a collection of the case law and authorities supporting such confidence, sce McDougal \& Leighton, The Rights of Man in the World Conmusuity: Constitutional Illusions Viersus Rational Action, 59 YaIE L.J. 60, 104 n.240 (1949). 
The major purpose of the Constitutional Convention in embodying the concept of separation of powers in the Constitution, was not to divide the policy-making function of government among its several branches as an end in itself, but rather to do so in order that the formulation of policy should not trench upon the individual rights of citizens. Its real purpose must be kept in mind when considering the manner in which the concept of separation of powers should properly apply to the conduct of foreign relations. A broad control by the President over the making of policy appears consistent with the intent of the drafters of the Constitution, so long as private rights are not placed in jeopardy.

The concept of separation of powers presupposes that the three functions of government can be distinguished. In the domestic realm this distinction is sufficiently difficult. In the field of foreign affairs this difficulty becomes virtually an impossibility. In the process of policy formulation there is an imperceptible shading of "diplomacy," which is an executive function, into "agreement-making," which may be executive or legislative. The process of agreement-making, in turn, includes those agreements which are "adjuclicative." Yet the great bulk of all international agreements is "legislative" in character. In fact the conduct of foreign relations is a continting process of policy formulation and application; it cannot be broken down into the allegedly neat categories of the doctrine of separation of powers. ${ }^{160}$

Any meaningful answer to the problem of the scope of the President's agreement power must be framed in terms of the necessities of national survival in the modern world. In these terms, it should be evident that a broad degree of presidential control over the foreign affairs of the nation is in no sense incompatible with the principles on which our government was built. The President is in a better position than the electorate, or either of the other branches of government, to give informed guidance in the conduct of foreign affairs. Reasonably, he should be accorded a broader discretion in establishing foreign policy than domestic policy : the Congress, whose members are elected largely on the basis of local issues, possesses a greater degree of information and competence in domestic matters than it does in the foreign field.

Furthermore, it is a primary requisite of the conduct of foreign affairs that the nation be able to act swiftly, and secretly, at need. Congress is poorly equipped to meet either of these requirements. In the domestic field, we can afford friction among the three branches of government, which, by its effect of slowing decision and inducing compromise, has the consequence of promoting the responsiveness of policy makers to the country as a whole. ${ }^{101}$ But

150. "The strength of Congress consists in the right to pass statutes; the strength of the President in his right to veto them. But foreign affairs . . . cannot be brought within the scope of statutes .... [Foreign affairs] cannot be provided for beforehand by laws general in application, but minutely particular in wording." 1 BRYCE, THE ANEERCAN Coamon wealth 224, 220 (3d ed. 1895).

151. See Brandeis' dissenting opinion in Myers v. United States, 272 U.S. 52, 240 (1926). 
in matters involving the external relations of the nation, this friction may become a great source of serious danger. This is far more true today than in 1787. And it is inevitable that the needs of the nation for a unified and effective foreign policy will increase with the years. As in the past, these needs must be met by a process that is essentially pragnuatic, which will result in a gradual, case by case delineation of the subject matter for presidential agreements, on the one hand, and for treaties and congressionalexecutive agreements, on the other. What the course of this delineation will be can never be fully predicted in advance, for it necessarily depends upon particular situations and the internal and external stresses with which the nation is faced. Consequently, the extent of the President's power in foreign affairs must vary with the context of events in which it must be exercised. The degree of crisis and the amount of time available for decision have customarily determined the scope of the President's substantive powers in the field of foreign affairs, and, therefore, the scope of his authority to implement these powers by means of appropriate international agreements. Where the emergency is great and time is short, the President has consistently been recognized to possess powers which, in less critical periods, might be held to extend too far. This result has been both desirable and inevitable. It is consistent with the intent of the men who drafted the Constitution that the method of democracy be one of adjustment and compromise, guided always by the indispensable consideration that the power of the President to conduct our foreign relations must keep pace with the necessities of national survival.

\section{Legal Consequences of Executive Agrechents}

Generally, the legal consequences of valid presidential agreements do not differ significantly from those of treaties or of congressional-executive agreements. ${ }^{152}$ Virtually all the legal limitations of all three methods are customarily attributed to domestic, as opposed to international, law. Of course, the line separating the "international" from the "domestic" consequences of an international agreement is difficult to draw. In the modern world international and domestic affairs are inevitably interrelated. Moreover, the term "domestic effect" itself has two meanings: it may refer to the fact that an international agreement is in conflict with municipal law, or it may have reference to the broader proposition that the agreement will affect in some fashion the private rights of citizens within the country in question.

Under the municipal law of the United States there is no question that in an appropriate judicial proceeding a presidential agreement is just as enforceable as a treaty. ${ }^{153}$ It is also recognized that presidential agreements may modify, or even terminate, prior treaties. ${ }^{154}$ Similarly, although the issue

152. The one important caveat to this general rule is that presidential agrecments, unlike treaties, may not be able, in certain contexts, to overrule prior congressional acts. See text at notes 174-77 infra.

153. United States v. Pink, 315 U.S. 203 (1942); United States v. Belmont, 301 U.S. 324 (1937). 
seldom arises, by the better view an executive agreement can override state law. ${ }^{155}$ To hold otherwise would be to subject the foreign policy of the nation to the whims of a single state. The only judicial decisions squarely presenting the question, the Belmont ${ }^{150}$ and Pink ${ }^{157}$ cases, have held that presidential agreements are superior to inconsistent state legislation. Some commentators have argued that Pink and Belmont mean that presidential agreements may override state legislation only when supported by the President's constitutional power to recognize foreign governments. But there is no reason to limit the rule of these cases so closely.

The domestic consequences of presidential agreements probably can be superseded by subsequent congressional legislation in those fields in which Congress possesses independent power to act. ${ }^{158}$ This seems an a fortiori conclusion from the established proposition that Congress possesses such power with respect to a prior treaty. ${ }^{150}$ The constitutional basis of this familiar principle is the supremacy clause, ${ }^{100}$ which, in making the Constitution, laws, and treaties the supreme law of the land, has been construed to give effect to the law or treaty most recent in time. Although the supremacy clause makes no mention of presidential agreements, they might now be considered as included by implication, since it has generally been recognized that they may modify or even terminate treaties. ${ }^{161}$ So construed, the supremacy clause enables subsequent legislation to prevail equally over treaties

154. "[T]reaties of the United States have been terminated on several occasions by the President, now on his own authority, now in accordance with a resolution of Congress, at other times with the sanction simply of the Senate." Corwin, The President: OFFice AND Powers 243 (2d ed. 1941). For the historical development of the presidential power of termination, see $i d$. at $416 \&$ n.107. This proposition is impliedly recognized in Charlton v. Kelly, 229 U.S. 447, 474, 476 (1913): "The executive department having thus elected to waive any right to free itself from the obligation [of the treaty], it is the plain duty of the court to recognize the obligation ...." President Roosevelt terminated at least two treaties under his independent constitutional powers : the extradition treaty with Greece, in 1933, and the Treaty of Commerce and Navigation with Japan, in 1939. See CoRwin, op. cit. supra, at 417.

155. See Hearings before Subcommittee of Senate Committec on the Judiciary on S.J. Res. 1 \& S.J. Res. 43, 83d Cong., 1st sess. 247 (1953).

156. United States v. Belmont, 301 U.S. 324 (1937).

157. United States v. Pink, 315 U.S. 203 (1942).

158. See, e.g., Hearings, supra note 155 , at 224 ; Hearings, supra note 141, at 420 ; MacChesney et al., The Treaty Power and the Constitution: The Case Against Amendment, 40 A.B.A.J. 203, 205 (1954); Sutherland, The Bricler Amendment, Eitrculize Agreements, and Imported Potatoes, 67 HARv. L. Rev. 281, 287 (1953); Lissitzyn, Thc Legal Status of Executive Agreements on Air Transportation, 17 J. AIr L. \& Conn. 436, 444 (1950).

159. See Hearings, supra note 155 , at 40-41; Moser v. United States, 341 U.S. 41 (1951) (dictum); Pigeon River Improvement Co. v. Cox, 291 U.S. 138 (1934) (stme).

160. U.S. Const. art. VI, cl. 2

161. See text at notes 174-76 infra discussing the inclusion of presidential agreements under the supremacy clause, for the purpose of modifying prior congressional legislation by presidential agreement. 
and presidential agreements. Furthermore, Congress may limit the President's power to make effective agreements in other ways: it can withhold appropriations, or refuse to enact implementing legislation where such is needed.

International agreements of all kinds, including presidential agreements, are limited by the guarantees of private rights contained in the Constitution. Although the First Amendment by its words limits only the operations of Congress, it has consistently been interpreted to apply with equal force to the other branches of the Federal Government, including the President. ${ }^{102}$ The applicability of the First Amendment to all branches of the Federal Government is confirmed by the Fifth Amendment:

"Read literally, the First Amendment of the Constitution forbids only Congress to abridge these freedoms. But as the due process clause of the Fourteenth Amendment extends the prohibition to all state action, the due process clause of the Fifth must extend it to all federal action."103

All the other constitutional Amendments relating to the Federal Government are phrased in terms which restrict all its branches, including the Executive. It thus appears that the language of the Constitution affords no ground for apprehension that a presidential agreement might contravene private rights. This conclusion is justified by numerous opinions of the Supreme Court. ${ }^{104}$ Since no agreement has ever been found unconstitutional, these judicial statements are dicta in the technical sense, but they reflect a consistent and unequivocal attitude of judicial vigilance.

In addition to constitutional limitations, there are several practical safeguards against infringement of constitutionally guaranteed rights by a presidential agreement. The pressure of public opinion and other political considerations have always served as a deterrent to reckless presidential action. And Congress can refuse to implement legislation or to provide appropriations. The fact that no presidential agreement has ever been declared unconstitutional should thus be a cause for confidence rather than concern.

As a matter of municipal law presidential agreements may be of as long

162. See $\mathrm{M}$ IacChesney et al., supra note 158, at 205.

163. Edgerton, J., in Joint Anti-Fascist Refugee Committee v. Clark, 177 F.2d 79, 87 (D.C. Cir. 1949) (dissenting opinion).

164. See, e.g., Missouri v. Holland, 252 U.S. 416,433 (1920) (dictum); Geofroy v. Riggs, 133 U.S. 258, 267 (1890) (same); The Cherokee Tobacco, 11 Wall. (78 U.S.) 616, 620-21 (1870) (same). These statements all relate to treaties, and would apply a fortiori to presidential agreements. The dissent of Chief Justice Vinson in Youngstown Sheet and Tube Company v. Sawyer, 343 U.S. 579, 667 (1952), does not in any way qualify this conclusion. The view expressed in the opinion of the Court was nut that the President's seizure was per se a violation of the Fifth Amendment, but rather that here the President had usurped the law-making function, there being no congressional legislation authorizing the seizure. Vinson merely contended that existing legislation did in fact authorize the President's action, referring to the contemporary vorld situation and certain legislative statements of national policy, such as the North Atlantic Treaty. There was no intimation that such treaties permitted the President to contravene the Fifth Amendment. 
duration as international agreements of any other sort. The assumption that presidential agreements must terminate with the term of the President making them is without basis in fact and is largely being abandoned today. ${ }^{105}$ It is true that a large number of presidential agreements are of a temporary character or deal with matters which are immediately settled. But the frequency of short-term agreements does not mean that an agreement cannot legally be of longer duration. The Lansing-Ishii Agreement and the Gentlemen's Agreement with Japan are two of the better-known examples of long-term presidential agreements. ${ }^{166}$ Furthermore, it is inevitable that many presidential agreements dealing with important issues of foreign policy will have a long-continued effect upon the foreign relations of the United States. For example, the "Bases-Destroyers Deal" of 1940 is said to have played a part in directing the foreign policy of this country towards formation of the present North Atlantic defensive alliance. ${ }^{167}$

Nor do the doctrines of international law impose requirements upon presidential agreements as to formality or duration. No particular formalities are required to create a binding international agreement; indeed, an unwritten agreement may be valid. ${ }^{168}$ It is debatable whether a state which undertakes an obligation by ratification by an apparently competent organ may under international law later deny the competence of that organ. ${ }^{160}$ But whatever the ultimate prescription of international law upon this point, it is evident that any argument which seeks to prove the invalidity of a presidential agreement on the ground of the President's incompetence under international law, must assume the incapacity of the President to conclude the agreement under American constitutional law, which is, of course, the point at issue. Finally, duration of international agreements is not limited by international law; nations are obliged to continue honoring agreements according to their terms, in the absence of invocation of the various doctrines relating to termination, such as rebus sic stantibus. But in practice it may happen that agreements will not continue to be observed when the undertaking becomes too onerous, even though the international obligation be violated. The policy considerations which might cause a nation to break an international agreement are not likely to vary with the constitutional form in which the agreement is cast.

Thus, by the doctrines of both international and municipal law, the legal consequences of a treaty, an independently concluded executive agreement, and a congressional-executive agreement are substantially the same.

165. Except by certain proponents of the Bricker Resolution, who continue hopefully to repeat the ancient misapprehension. See Hearings before a subcommittec of the Senasc Contmittee on the Judiciary on S.J. Res. 130, 82d Cong., 2d sess. 439 (1952).

166. See Coriwin, The Constitution and Wórld Organization 43 (1944).

167. Ibid.

168. The Legal Status of Eastern Greenland, P.C.I.J., Ser. A/B No. 53, pp. 22-147 (Judgment 1933).

169. See 5 Hackworth, Digest of INT'L LAw, 393 (1943); LaUterpacit, REpoRT on the Law of Treaties A/CN. 4/63 (U.N. Int'l Law Comm'n) 157-73 (1953); 29 Am. J. InT'L Law, L. of TrEaties 992-1009, 1029-44 (Supp. 1935). 
Power of Congress to Regulate Presidential Agreedents

The scope of the President's power to conclude international agreements has, thus, never been clearly defined, and can only be indicated approximately by an estimate of the requirements of modern international relations guided by the various exercises of presidential power which have been recognized as constitutional during the course of our history. A question of equal current interest and at least equal difficulty is to what extent may Congress constitutionally limit the President in the exercise of this power. Senator Bricker's proposed limitations upon the President's agreement-making ability took the form of a constitutional amendment. But the argument was frequently advanced in the course of the controversy over the Bricker amendment that Congress already has sufficient power to accomplish the result of the amendment. This is the theory of the recent MrCarran Resolution "to impose limitations with regard to Executive agreements."170 Although that resolution does not make it entirely clear what types of agreements are intended to be affected, ${ }^{\mathbf{1 7 1}}$ it squarely presents the question of the power of the legislative branch to control the executive branch in the conduct of foreign affairs.

At the outset it should be understood what is meant by congressional "limitation" of the President's foreign affairs power. Congress has frequently authorized the President to act as its agent in matters pertaining to foreign affairs, and it has never been doubted that in such cases Congress controls the extent of the power delegated. This proposition is self-evident, although the overlapping of congressional and presidential powers so common in this sphere may obscure the issue. If the powers which Congress purports to delegate to the President are not as broad as those cognate powers which he possesses independently with respect to the same subject matter, it may nut even appear that any limitation upon the President's own powers was intended. And if such an intent should appear, its constitutionality would be most dubious. If, on the other hand, the powers which Congress delegates to the President are broader than those which he independently possesses, Congress can define the extent of the delegation, and subsequently revolie it if it wishes.

The doctrine is established that Congress may, acting within the scope of its enumerated powers, override the domestic consequences of a presidential agreement by subsequent legislation. Similarly, Congress may achieve the same result by imposing restrictions in advance on the President's power to make international agreements. Normally the method employed by Congress is to

170. S.J. Res. 2, 83d Cong., 1st sess. (1953).

171. The term "executive agreements" may or may not be taken to include presidential declarations of policy issued jointly with other nations, such as the Declaration of Lima in 1938, the Atlantic Charter, the declaration with respect to atomic energy, or the United Nations declaration on the Korean armistice. 
prescribe a certain method of exercising the power in question, and thus by implication to exclude all other means. 172

The proposition has been put forward that the power of Congress to regulate the scope of presidential agreements is only co-extensive with the powers which Congress itself possesses to act in the field of foreign affairs or to regulate domestic consequences. ${ }^{173}$ As a matter of logic this is a reasonable doctrine, for it is difficult to conceive by what authority Congress could prevent the President from acting in an area to which his powers extend and those of Congress do not extend even indirectly. Although the foreign and domestic powers of Congress are extremely broad, there may exist certain areas in which the President's constitutional power to conclude international agreements may be exercised to produce domestic consequences beyond the pale of congressional regulation. In these areas the President could enter into such international agreements as he might desire, unrestricted by any power in Congress either to limit him in advance or to overrule subsequently the domestic consequences of his action. Similarly, the President and two-thirds of the Senate could conclude treaties in this residual area, and Congress would be powerless to override their domestic effects.

This reasoning leads to the conclusion that the "domestic effects" doctrine must be qualified: it is not categorically true, as has been so often argued, that Congress can abrogate the domestic effect of any international agreement; rather, Congress can overrule an agreement only when it concerns a subject with respect to which Congress could have legislated domestically. In the vast majority of cases this limitation on the power of Congress will not be pertinent; the constitutional powers of Congress have been recognized to be increasingly broad in recent years. Indeed, it is difficult to imagine a situation in which the President is likely to make an executive agreement whose domestic consequences are not within one or another of the powers of Congress as currently construed. In the case of a treaty, however, the likelihood might be greater. But even then Congress would not be powerless. It could still refuse appropriations or such implementing legislation as might be required. And it is entirely conceivable that if a court felt the necessity sufficiently great, the domestic powers of Congress might be construed as broad enough to meet the situation.

The constitutional power of Congress to limit the President in the exercise of his agreement-making power is dependent on the viability of the doctrine

172. This may have been what occurred in the Capps case, discussed in text at note 178 infra.

173. This proposition in its inverse form, was stated by Mr. Justice Jackson, concurring in the Steel Seizure case: "When the President takes measures incompatible with the express or implied will of Congress, his power is at its lowest ebb, for then he can rely upon his own constitutional powers minus any constitutional powers of Congress over the matter. Courts can sustain exclusive presidential control in such a case only by disabling the Congress from acting upon the subject. Youngtown Shect \& Tube Co. v. Sawyer, 343 U.S. 579, 637-38 (1952). 
that presidential agreements cannot supersede congressional legislation. The Supreme Court has "intimated that the President might act in external affairs without congressional authority, but not that he might act contrary to an Act of Congress."174 The constitutional justification for this rule is that the President's power to make international agreements derives from his position as Chief Executive; since by Article I, section 7, the President has no power to repeal existing federal law, he cannot accomplish an indirect repeal by means of a presidential agreement. ${ }^{1 i 5}$ But, on the other hand, presidential agreements may be ranked on a par with congressional enactments by the supremacy clause. The Pink case reasoned that a treaty is a "Law of the Land" under the supremacy clause and that, "such international compacts and agreements as the Litvinov Assignment have a similar dignity." The Court relied on the Federalist, No. 64, for the proposition that "All constitutional acts of power, whether in the executive or in the judicial department, have as much legal validity and obligation as if they proceeded from the Legislature . . .." In the Pink case, however, the issue was whether presidential agreements could override contrary state laws. The Court may have intended to include presidential agreements within the supremacy clause only for this purpose. Furthermore, the Litvinov Assignment was an act of recognition over which the President has exclusive constitutional control. It is therefore possible that the Court, in a case involving an agreement regarding a subject over which Congress also has control, would refuse to hold such an agreement the "Law of the Land" capable of overriding a prior act of Congress. ${ }^{176}$

The restrictive view that, where constitutional powers are concurrent, Congress may occupy the field by prior legislation may often result in highly undesirable rigidity in the conduct of foreign affairs. It might therefore be argued that, since Congress has power to override the domestic consequences of presidential agreements, the President should in times of crisis possess a reciprocal power within the areas of his concurrent constitutional competence. ${ }^{17 \tau}$ Thus far there appears to be no conclusive answer to this question,

174. Youngstown Sheet \& Tube Co. v. Sawyer, 343 U.S. 579, 635-36 n.2 (1952) (concurring opinion of Jackson). The commentators have been in general agreement. See, c.g., Corwin, The President's Control of Foreign Relations 120 (1917); Hearings before Subcommittee of Senate Committec on the Judiciary on S.J. Res. 1 is S.J. Res. 43, 83d Cong., 1st sess. 224, $247 \& n .57$ (1953) ; MacChesney et al., The Traty Pocter and the Constitution: The Case Against Amendment, 40 A.B.A.J. 203, 205 (1954). Lissitzyn observes: "[W]hile a treaty, if self-executing, can supersede a prior inconsistent statute, it is very doubtful whether an executive agreement, in the absence of appropriate legislation, will be given similar effect." Lissitzyn, The Legal Status of Executize Agrecucnts on Air Transportation, 17 J. AIR. L. \& Cosrs. 436, 444 (1950).

175. Hearings, supra note 174 , at 235 .

176. Still, Presidential agreement, whether or not accompanied by any act of recognition, should properly override contrary state law. See text at notes 155-57 supro.

177. There appears to be no wholly satisfactory authority for this proposition. In Watts v. United States, 1 Wash. Terr. (N.s.) $28 S$ (1870), a case which is sometimes citcd in support of this conclusion, the court may have relied upon the doctrine of "political 
although the majority of commentators appears to take the restrictive view and one judicial decision may be regarded as affording them some support. ${ }^{178}$ However, neither policy nor logic may require this result. The balance between presidential and congressional powers should be worked out in a manner essentially pragmatic. It might be desirable to conclude, as with respect to treaties and congressional statutes, that the latest expression in point of time prevails.

The question remaining, therefore, is what specific constitutional powers does Congress possess for limiting the power of the President to conclude international agreements. The answer must, of course, be in terms of congressional power to restrict the President's substantive foreign affairs powers. Principal among the powers conferred on Congress is the authority to support and to regulate the armed forces. ${ }^{170}$ Congress has sole control over all appropriations for the support of the military, and through the budget it has complete discretion in determining the size of the services. The President may exhort, but he cannot control, the Congress, except insofar as he may be able to force the legislative branch to meet his demands-or make up his deficits-by committing the armed forces to action under his independent powers. However, Congress cannot use its power of "government and regulation" for the purpose of limiting the authority of the Commander in Chief to use the armed forces in appropriate circumstances. ${ }^{180}$ Thus the Selective Service Act of 1940 provided that troops drafted under the Act could be used only in the Western Hemisphere and the territories of the United States. But the President sent troops to Iceland without a reference to the Act, and his action was never challenged. ${ }^{131}$ So also, the Senate committee report, on the assignment of American forces to European duty in implementation of the North Atlantic Treaty, is careful to state that the suggested requirement of congressional approval of any assignment of ground forces to Europe was not "concerned with armed forces which the President might send abroad under his constitutional powers as Commander in Chief of the Army and Navy." 182

questions" or even upon the presumed exclusive power of the President to settlc boundary disputes with foreign nations. See McDougal \& Lans, Treaties and Congrcssional-Exaccutive or Presidential Agreements: Interchangeable Instruments of National Policy, 54 YALE L.J. 181, 318 \& n.53 (1945).

178. This is the Steel Seizure case, Youngstown Sheet $\&$ Tube Co. v. Sawyer, 343 U.S. 579 (1952). However, this case may not be determinative of the issue, owing to the impossibility of finding in the various opinions any clear constitutional theory to which a majority of the Justices could agree. Moreover, despite its evident relationship to foreign affairs, the issue involved in Youngstown was primarily of domestic concern.

179. U.S. Const. art. $1, \S 8$.

180. "Congress may increase the Army, or reduce the Army, or abolish it altogether; but so long as we have military force Congress cannot take away from the President the supreme command." Swaim v. United States, 28 Ct. Cl. 173, 221 (1893), aff'd, 165 U.S. 553 (1897).

181. See Report on Powers of the President 15.

182. Sex. Rep. No. 175, 82 d Cong., 1st sess. 8 (1951). To avoid the constitutional 
Congress may be able to use its authority to govern and regulate the armed forces to restrict the power of the Commander in Chief in another way than by limiting the military resources at his disposal. The President can use the forces of the United States under his authority as Commander in Chief only when such action is in the national interest. It has been argued that although this constitutional power cannot be restricted by Congress under its authority to govern and regulate the military, Congress can restrict the President in his exercise of this power by defining more narrowly the "interests" of the United States which the President may defend. ${ }^{183}$ This is said to be the constitutional basis of various acts of Congress regulating the disposition of military equipment in the years preceding the second World War. ${ }^{182}$ It has been suggested that this legislation could have constitutionally prohibited the President from sending over-age destroyers to Britain, not because the statutes limited the scope of presidential power as such, but because they restricted the interests for which the President's authority as Commander in Chief could constitutionally be exercised. Conversely, the constitutional theory underlying the Lend-Lease Act of 1941 may have been not that Congress was delegating power to the Commander in Chief, but that it was redefining the defensible interests of the United States to include the defense of foreign governments. As a matter of fact, of course, legislation limiting the exercise of his power limits the President's power, for he is prevented from engaging

question and quiet the misnamed "Great Debate," the report provided for consultation among various executive departments and "approval" of executive policy by Congress; but, in effect, the requirement of "approval" amounted only to a suggestion for cooperation. The debate had been precipitated by Senator Taft: "The President has no power to agree to send troops to fight in Europe in a war between the members of the Atlantic Pact and Soviet Russia. This matter must be debated and determined by Congress and by the people of this country if we are to maintain any of our constitutional frecdoms." N.Y. Times, Jan. 14, 1951, § IV, p. 1, col. 3. To give effect to this position, a resolution was submitted by Senator Wherry, providing that "no ground forces of the United States should be assigned to duty in the European area for the purposes of the North Atlantic Treaty pending the formulation of a policy with respect theretu by Congress." N.Y. Times, Jan. 9, 1951, p. 1, col. 4. This position was strongly opposed by the administration, President Truman declaring that, although he would consult with congressional committees, and would welcome a resolution of the Senate approving his action in sending troops to Europe, he would be ultimately guided by the policy which he thought necessary under the circumstances. N.Y. Times, Jan. 12, 1951, p. 1, col. 5. Three months later the Senate voted, 69 to 21, to approve the President's action in sending four additional divisions to Europe, and expressed its opinion, without purporting to bind the President, that Congress should have the right to approve any further shipment of troops to NATO. N.Y. Times, April 5, 1951, p. 12, col. 2. Senator Taft voted in favor of this resolution.

183. See Wright, The Lend-Lease Bill and International Law, 35 Ass. J. Is:' L. 305 (1941).

184. Id. at $305 \&$ n.5. The authorities are uniform in recognizing this power in Congress to limit the authority of the Commander in Chief. See Acquisition of Naval \& Air Bases in Exchange for Over-Age Destroyers, 39 Ops. Atr'y Ges. $4 \$ 4$ (1940); Wright, Editorial Comment, 34 Axs. J. INT'L L. 680 (1940); Briggs, Neglected Aspects of the Destroyer Deal, 34 Axr. J. INT'L L. 569 (1940). 
in various activities which would otherwise be within his authority as Commander in Chief.

Although the President has exclusive power to direct the use of military forces, Congress has often attempted to assert its influence. It has frequently enacted neutrality legislation and embargoes on the shipment abroad of military equipment. The constitutionality of these acts has not been questioned. On the other hand, the President has ignored legislative attempts to restrict his power to send troops abroad. And this action too has generally been accepted as constitutional. The only distinction between these cases lies in the extent to which they involved the interests of the United States. In terms of the classic doctrine, the cases might be said to turn on whether our own interests, or merely those of other nations, are affected. Thus it could be argued that Congress cannot prevent the shipment of troops to Iceland because the President is acting in the interests of the United States, but that Congress can prevent the shipment of arms to Britain because only Britain's interest is involved. In reality, of course, the interests of the United States are affected in both cases, and the only valid distinction is one of degrec.

It appears, therefore, that where the interests of the United States are not immediately threatened, Congress may be able constitutionally to limit the President's power to act as Commander in Chief and, therefore, his ability to make agreements in that capacity. But these restrictions are presumably constitutional only if they leave to the President considerable freedom to exercise his war powers in defense of the interests of the United States. Neutrality acts have always given the President considerable discretion to meet emergencies. And, "in the face of a real threat to the security of the country the President would be justified in using his powers as Commander in Chief to protect the United States, even in contravention of a duly enacted neutrality law ...."185 Which interests the President may defend in disregard of a statute limiting his actions is a matter of fact to be cletermined in each set of circumstances. And since the Presiclent has traditionally initiated the foreign policy of the United States, he is the one who determines what these interests are. This is an inevitable and indispensable consequence of our form of government. It is not a case of the President enlarging his power "at the expense of Congress by simply deciding that a national emergency exists."186 In foreign affairs it is necessary that the President "may

185. Report on the Powers of the President 20. Neutrality legislation is, of course, a traditional and familiar exercise of the constitutional power of Congress to declare war. Id. at 19. Customarily, the major effect of such legislation is to regulate the conduct of private citizens of the United States when foreign war exists, rather than to determine the international status of the United States as a nation. Nevertheless, it may conflict with the international policies of the President.

186. See Schwarzer \& Wood, Presidential Power and Aggression Abroad: A Constitutional Dilemma, 40 A.B.A.J. 394, 395 (1954) (citing Youngstown Sheet \& Tube Co. v. Sawyer, 343 U.S. 579 (1952)). 
legitimately take action ... which leaves Congress no alternative but to follow the lead he has chosen to give."187

The argument has been made that since the Constitution confers upon Congress alone the power to declare war, the President is bound not to take any action which will increase the danger of war, lest he thereby usurp the congressional power by creating a situation in which Congress has no choice but to declare war. This argument presupposes a sequence of events which might possibly take place. But practical difficulties would prevent it from ever being employed as a constitutional doctrine. It surpasses human competence to isolate particular events which more than others may be said to have tended towards war. Historians are often unable to agree upon this question even in the perspective of centuries. It would be much less possible to make a determination amid the political and emotional stresses of the moment. "There is no constitutional doctrine to this effect, and there can be none if the Nation is to survive." 188

The President's power over the administration of foreign affairs has always been recognized to be almost exclusive of congressional limitation. However, there have been many attempts in Congress during our history to encroach upon this presidential power; and though none of the cases involved an international agreement, it is instructive to note that the President emerged as victor in each of these contests. ${ }^{189}$ For example, in 1826 an attempt was made to persuade Congress to impose its foreign policy upon the President by attaching certain conditions to an appropriations bill for the mission which the United States sent to the Panama Congress. However, Webster argued that the conditions were an unconstitutional invasion of the power of the President, and that the proper manner of expressing congressional disapproval was by resolution or by refusing the appropriation altogether. The conditions were stricken from the bill. In 1864 the House, despite arguments that its action expressed a novel theory of administration of foreign affairs, approved a resolution that the President ought, as a constitutional matter, to recognize that Congress possesses "an authoritative voice" in the formulation of foreign policy. However, similar resolutions in the Senate never reached a vote. And in 1876 President Grant vetoed an innocuous congressional resolution requesting the Secretary of State to express thanks to Argentina and the Republic of Pretoria for their congratulations on the first centennial of American independence. With an overdose of caution but a probably correct view of the Constitution, the President feared that this suggestion could be construed as an invasion of his power. Thus, the power of Congress has been limited to the offering of suggestions regarding the conduct of our foreign policy.

The President exercises a nearly unlimited power in the recognition of

187. See Laski, The Aaterican Presidency 171 (1940).

18S. Refort on the Powers of the President 18.

189. These examples are drawn from Coswrn, The Presment's Control of Furelc: RELATIONS 40-46 (1917). 
other governments. ${ }^{100}$ In 1818 an appropriations bill was introduced to finance a minister to "the United Provinces of the Rio de La Plata" at the President's discretion. Even though it was argued that this merely expressed the opinion of Congress and in no way sought to dictate the President's recog* nition policy, the bill was defeated and nothing further was done in the matter until the President specifically invited congressional action four years later. President Jackson left the recognition of Texas to Congress "on the ground of expediency," but stated that his action was not to be regarded as an expression of opinion on the constitutional issue. And when a bill was introduced to provide a salary for a minister to Texas, the adjective was stricken from "independent Republic of Texas" for it was thought to usurp presidential prerogative. Again, despite strong congressional sentiment, the Senate Committee on Foreign Relations concluded that it would be unconstitutional to pass a joint resolution directing the President to recognize the independence of Cuba. A subsequent resolution referring to Cuba as "independent" was approved only after the President had appealed to Congress to settle the Cuban problem. These few events indicate the long recognized incapacity of Congress to limit the President's power of recognition.

In the recent Capps case, ${ }^{101}$ a presidential agreement regulating the importation of potatoes was invalidated by the Fourth Circuit on the ground that the agreement contravened prior congressional legislation under the commerce clause. ${ }^{192}$ Capps presents, however, a less than satisfactory treatment of the constitutional question. First, it is not even clear that the method of presidential action provided by Congress was intended to be exclusive. Another

190. Examples are from $i d$. at 73-82.

191. United States v. Guy W. Capps, Inc., 204 F.2d 655 (4th Cir.), cert. granted, 346 U.S. 884 (1953).

192. Since it has been said that this case demonstrates the power of Congress to limit the President's independent authority to make international agreements, its facts are worth noting. In 1948 the President entered into an agreement with Canada, Control of Exports from Canada, Nov. 23, 1948, T.I.A.S. No. 1896, for the purpose of preventing the importation from that country of table stock potatoes. Canada undertook to refuse export permits of all table stock potatoes intended for the United States, and to issue permits for seed potatoes only on showing that they were destined for a locality in which there was a "legitimate demand," and only upon proof, in the form of a provision in the contract with the American importer, that the potatoes would not be diverted for consumption purposes. At the time this agreement was made, Congress had already provided legislation dealing with the problem. The Agricultural Act of 1948, 62 STAт. 1247 (1948), 7 U.S.C. $\S 624$ (1952) authorized the President, if the importation of Canadian potatoes appearcd to be undermining the American market, to order an investigation by the Tariff Commission and, if in his opinion the Commission's report warranted, to impose limitations of up to $50 \%$ upon the quantity of potatoes imported. The Act did not authorize the President to proceed in any other way. The question presented to the court was whether the United States could maintain an action for damages for the breach by an American importer of the provision in his contract required by the presidential agrcement, by which he agreed not to resell imported potatoes for table stock. There was a sufficient showing of damages occasioned by defendant's breach of contract: the United States purchased all table stock potatoes which American growers and dealers were unable to sell at parity, 
section of the Act in question may be interpreted to show a congressional intent to permit the President to deal with the problem by means of executive agreement as well. ${ }^{193}$ More important, the decision does not clearly recognize the question whether the President possesses any independent power in the commerce field. If he does not, the issue is only the extent to which Congress has delegated its own powers to the President to deal with a subject solely within congressional competence, and no question of the authority of Congress to limit the President's independent powers is involved. The Fourth Circuit's opinion contains statements supporting both the proposition that the President has no independent power, and its converse. ${ }^{194}$ If he does possess independent power to act in this field, but if the method established by Congress was intended to be exclusive, the power of the President to follow a different procedure should depend upon judicial appraisal of the degree of emergency eliciting his action. If the context of events indicates that there was not sufficient time for the President to have used the method prescribed by Congress, then he might be held to have had constitutional sanction unilaterally to override the legislation. Whatever the ultimate disposition of the Capps case, the decision shows a desire on the part of the courts to review presidential agreements in appropriate circumstances.

Far more sweeping than the reasoning in Capps is another argument advanced by those who wish to limit the power of the President to conduct foreign affairs. Under the necessary and proper clause ${ }^{105}$ Congress is said to possess power to regulate presidential agreements of all types. ${ }^{190}$ The argument runs as follows: the President's power is wholly derived from the Constitution; the Constitution confers on Congress the power to make all laws "necessary and proper" to carry out not only its own constitutional

and the diversion of defendant's potatoes to the consumption market had pro tanto increased the quantity of potatoes which the United States was obliged to purchase. The fourth circuit nevertheless held that there could be no recovery, on the ground that the presidential agreement was invalid.

193. See Sutherland, The Bricker Amendment, Execulize Agrecments, and Imported Potatoes, 67 HaRv. L. Rev. 281, 291 (1953).

194. "The power to regulate foreign commerce is vested in Congress, nut in the executive ... and the executive may not exercise the power by entering into exceutive agreements ...." United States v. Guy W. Capps, Inc, 204 F.2d 655, 658 (4th Cir. 1953). See also id. at 659 . But "whatever the power of the executive with respect to maling executive trade agreements regulating foreign commerce in the absence of action by Congress, it is clear that the executive may not through entering into such an agreement avoid complying with a regulation prescribed by Congress." Id. at 659-60.

195. U.S. Const. art. I, \$ 8, cl. 18.

196. "It seems clear that the necessary and proper clause yests Congress with the power to make all laws necessary and proper to carry the executive power into effect; and that Congress can, therefore, under the existing Constitution, regulate esecutive agreements." Statement by A. J. Schweppe, Hearings before Subcommillec of Senale Committee on the Judiciary on S.J Res. 1 o S.J. Res. 43, 83d Cong., 1st sess. 66 (1953). See also id. at 43; Hatch et al, The Treaty Pouter and the Constifution: The Case for Amendment, 40 A.B.A.J. 207, 259 (1954). 
powers but-by the language of that clause-those of the President as well; therefore Congress has legislative control over all the powers possessed by the President, and since the President cannot contravene valiclly existing legislation, Congress has power to regulate all presidential agreements.

It is hard to envision a way to do greater violence to the necessary and proper clause. The purpose of the clause is to make possible the effectiveness of the powers which the Constitution confers upon the various branches of the Government, by authorizing Congress to legislate for this purpose in areas where it is otherwise without power. The very presence of the necessary and proper clause is proof that Congress does not otherwise possess power to legislate in these areas. If Congress had that power, the clause would be superfluous. Congress may refuse to pass implementing legislation under the necessary and proper clause and thus frustrate the effectiveness of a presidential agreement. But this does not mean that the clause gives Congress independent power to legislate in every case in which it is enabled by this provision to pass implementing legislation supported by the powers of another branch of the government. Such an interpretation would violate the fundamental principle of balanced powers upon which our government was built.

It may in conclusion be recalled that Congress is not without power to limit the effectiveness of presidential agreements even in areas to which its own powers of legislation do not extend. We have seen that Congress can limit the effective exercise of the constitutional powers of the President by refusing appropriations or necessary legislation. Furthermore, so long as the safety of the United States is not endangered, Congress has power to limit the size and disposition of the armed forces, with a consequent inhibiting effect upon the President's power to take military action. Similarly, subject to the same condition, Congress may apparently define the territory, ${ }^{107}$ nations, and individuals which it is in the interest of the United States to defend, again limiting the President's exercise of his power as Commander in Chief. Nevertheless, the President, by virtue of his position as the initiator of foreign policy, is in a position in many cases to define what are the interests of the United States in furtherance of which he may exercise his constitutional authority.

In addition to these various legal controls possessed by Congress, purely practical considerations are customarily effective in preventing extreme attempts by the President to formulate the foreign policy of the United States in disregard of Congress. ${ }^{108}$ Obviously some Administrations are more responsive to congressional opinion than others; but no President who expects to see his program carried into effect can afford to ignore the legislature. ${ }^{100}$

197. Rogers, World Policing \& the Constitution 89 (1945), states that Congress can limit the President's use of the armed forces "in almost any way, such as to areas, for example." It would seem that this states the proposition too broadly.

198. The Senate possesses an incidental control over the activities of the President by virtue of its power to refuse consent to the appointment of various important subordinates.

199. "In the interest of orderly procedure ... I feel that the Congress is entitled to know the considerations that enter into the determinations as to which procedures [execu- 
These congressional controls, in part based upon the language of the Constitution and in part stemming from deference to Congress' political power, should be sufficient to quell any fears that the independent authority of the President to conclude international agreements is not presently subject to adequate supervision. ${ }^{200}$ There is no need to indulge in fantasies of constitutional theory in an effort to interpret the necessary and proper clause to create a primary congressional function where the Constitution gives the President, but not Congress, a power to act. The experience of recent years has shown that the United States must be capable of prompt and sometimes secret action as an indispensable condition of survival. Plainly, this necessity may increase. Secrecy may often be required to negotiate defonsive agreements with our allies, and speed and singleness of purpose to counteract sudden aggression. If the Executive does not possess powers adequate for these occasions, no branch of government does. Our Constitution affords a vise compromise of function whereby leadership in dealing with foreign nations rests with the President, subject to constitutional restrictions and legislative powers vested in Congress. It would be extremely unwise to destroy the balancing of power effected by the Founding Fathers and to restrict the President further by strained interpretation of an inapplicable clause or by the rigidity and permanence of a constitutional amendment.

tive agreement or treaty] are sought to be followed." Statement by Seeretary of State Dulles, Hearings, supra note 196, at 828-29.

200. The recent statement by Secretary of State Dulles that "the Supreme Court has repeatedly held in the field of current conduct of foreign relations that the President is paramount, not subject to interference by Congress," Hearings, supra note 19i, at 892 . if intended to deny the existence of the various legislative controls outlined above, is clearly inaccurate. 


\section{THE YALE LAW JOURNAL}

BARRY R. BRYAN Article and Book Revieze Editor

Irving J. Alter Peter W. Anson Robert W. BEREND Daniel M. Berger MuRRY D. Brochin Richard C. CAHN Thomas N. Carruthers, Jr. Donald J. Cohn John W. Colleran Alan P. Colodny Edmund V. Conway Gerald M. Doppelt David A. DRExLer S. Gordon ElKins Joseph M. FieLd BARRY H. GarfinkeI

\section{EDITORIAL BOARD \\ Jerome A. Cohen \\ Editor-in-Chief}

\author{
William H. Dempsey, JR. Girald Walpin \\ Thomas F. Nelson . Managing Editor \\ GoRdon B. SPIVACK \\ Note and Comment Editors
}

Charles S. Haight, Jr. Stephen J. Pollak

Robert J. Harris Marvin N. Rimas

George C. Hastings Bernard S. Roduins

Ira Michael Heyman Norbert A. Schlet

Alexander P. Hoffmann Raymond M. Shainderg

Charles D. Isaac Walter E. Shuttlewortu

JeAnNe Ritchie Silver

$\begin{array}{ll}\text { Lawrence R. Klein } & \text { Monroe Silverdan } \\ \text { Charles S. Mechem, Jr. } & \text { Robert J. Sisk }\end{array}$

RalpH C. Menapace, Jr. ARLen Specter

Edward A. Miller Melvin Stein

Jon O. NEWMAN JohN T. SUBAK

Lawrence Newman Charles H. Vejvoda

Martin Oppenhemmer Roger A. Welch

Otis P. Pearsall Howard P. Willens

Richard H. Pershan George C. Zachinily

Marie McMahon

Business Secretary

\section{CONTRIBUTORS TO THIS ISSUE}

Willian Dwight Whitney. B.A. 1920, LL.B. 1924, Yale University; B.A. Juris. 1923, M.A. Juris. 1928, Oxford University. Member New York and United States Supreme Court Bars; Inner Temple (London), Barrister-at-Law. Former Special Assistant in antitrust to United States Attorney-General.

Craig Mathews. B.A. 1951, LL.B. 1954, Yale University. Member, Ohio Bar. 